\title{
Türkiye'de Kıdem Tazminatı ve İşsizlik Sigortası İkileminde Fon Tartışmaları
}

\section{Funding Discussions Regarding the Severance Pay and Unemployment Insurance Dilemma in Turkey}

\section{Mustafa Şen 1 (1)}

Öz

Pasif işgücü piyasası politikaları içerisinde yer alan işsizlik sigortası ve kıdem tazminat;; işsizliğin neden olduğu olumsuz sonuçları gidermeye yönelik önemli düzenlemelerdir. Türkiye'de kıdem tazminat, 1936 yılında ilk iş kanunu olan 3008 sayılı Kanun ile birlikte uygulanmaya başlamıştır. İşsizlik sigortası ise kurulma çabaları erken tarihlerde başlamasına rağmen, kıdem tazminatı uygulaması başta olmak üzere çeşitli nedenler gerekçe gösterilerek sürekli ertelenmiş ve nihayet 1999 yılına gelindiğinde 4447 sayılı işsizlik Sigortası Kanunu ile birlikte uygulamaya geçirilmiştir. İşsizlik sigortasıyla birlikte oluşturulan işsizlik sigortası fonunun giderleri başlangıçta sadece işini kaybedenlere yönelik iken 2008 yılından itibaren tüm işsizleri kapsayacak şekilde sürekli artş göstermiştir. Yapılan düzenlemelerle fonun gider kalemlerinin artması fonun etkinliği konusunda sürekli eleştirilere neden olmaktadır. Diğer yandan kıdem tazminatından işini kaybedenlerin çeşitli nedenlerle çok küçük bir kesimi yararlanmaktadır. Dolayısıyla işini kaybeden tüm çalışanların yararlanabileceği ve işverenleri ani ve yüklü ödemelerden kurtaran bir fon sistemin oluşturulması tartışmaları sürekli gündemdeki yerini korumaktadır. Kıdem tazminat fonunun oluşturulması yönündeki çalışmalar 1954 yılından günümüze kadar devam etmesine rağmen henüz bir sonuç alınamamıştır. Hazırlanmasında yasalar, yasa tasarıları, kalkınma planları gibi düzenlemeler, istatistikler ve bu alanda mevcut yayınlanmış literatür referans olarak alınan bu çalışmanın amacı, Türkiye'de etkin olarak kullanılamayan işsizlik sigortası fonu ile oluşturulması uzun yıllardır gündemde olan kıdem tazminat fonu tartşmalarının değerlendirilmesi ve bu yönde görüş ve önerilerin sunulmasıdır.

Anahtar Kelimeler

Kıdem Tazminat,, Kıdem Tazminatı Fonu, İssizlik Sigortası, İşsizlik Sigortası Fonu, Türkiye

1 Sorumlu Yazar: Mustafa Şen (Dr. Öğr. Üyesi), Karadeniz Teknik Üniversitesi, İktisadi ve İdari Bilimler Fakültesi, Çalışma Ekonomisi ve Endüstri ilişkileri Bölümü, Trabzon, Türkiye. E-posta: mustafasen061@gmail.com ORCID: 0000-0002-3690-7582 Conferences, 81. Advanced onlien publication. https://doi.org/10.26650/jspc.2021.81.929774 


\begin{abstract}
Unemployment insurance and severance pay mandated in passive labor market policies are important regulations aimed at eliminating the negative results of unemployment. Severance pay in Turkey was implemented in 1936 with the first labor law, Law No. 3008. Although the efforts to establish unemployment insurance began earlier, it was continuously postponed for various reasons; in particular, regarding the application of severance pay. Unemployment was finally put into practice in 1999 with the passing of Unemployment Insurance Law No. 4447. While the expenses of the unemployment insurance fund, created in combination with unemployment insurance, were aimed only at those who lost their jobs in the beginning, since 2008, this has continuously expanded to include all unemployed individuals. The increase in the expense items of the fund covered in the regulations has been the subject of constant criticism regarding the efficiency of the fund. However, for various reasons, only a small portion of those who lose their jobs benefit from any form of severance pay; therefore, discussions on the creation of a fund system to benefit all employees who lose their jobs that saves employers from obligations to produce sudden and heavy payments are a regular agenda item. Although the efforts to establish a severance pay fund have continued since 1954, no results have been achieved to date. In the preparations for the study, regulations, including laws, draft laws, development plans and published literature and statistics were used as a reference. The purpose of this study is to provide a comprehensive evaluation of ongoing discussions regarding the establishment of a severance pay fund in Turkey, which has been on the agenda for many years, offering an overview of various opinions, research, and suggestions in this direction, as the use of Turkish unemployment insurance fund falls outside of its aim.
\end{abstract}

\title{
Keywords
}

Severance Pay, Severance Pay Fund, Unemployment Insurance, Unemployment Insurance Fund, Turkey 


\section{Extended Summary}

In the 18th century, as a result of the gradual growth of capital and the weakness of labor against capital created by the Industrial Revolution, many challenges arose for maintaining gainful employment. At the core of these problems is the challenge of unemployment. During this time, industrialized countries implemented passive labor market policies, such as unemployment insurance and unemployment benefits, to prevent the risks caused by unemployment in the fight against poverty.

The passive policies that were used effectively to combat the surge in unemployment challenges that emerged following the Industrial Revolution aimed to eliminate the adversities caused by unemployment, provide unemployed at a minimum level of income assurance, as well as function to regulate the labor market. Industrialized countries have attempted to eliminate the challenges of unemployment with passive labor market policies from the early 1900s until 1974, when unemployment had not yet acquired a structural feature.

With the economic crises of the 1970s and the acceleration of globalization, particularly in the 1980s, unemployment gained a structural feature. In addition to passive labor market policies, active labor market policies were put into practice to create new business opportunities and increase employment. Although active labor market policies have increased since this time, passive policies remain among the dominant expenditures of countries for addressing anti-unemployment policies as the most common area of policy application.

Unemployment insurance, one of the basic applications of passive labor market policies, was first legally put into practice in England in 1911, the country where the Industrial Revolution began. In Turkey, despite the fact that unemployment insurance was included in development plans and draft laws were issued, the policy was not implemented until 1999 for various reasons; especially the consideration of severance pay. Unemployment insurance was established by Law No. 4447 enacted on August 25, 1999, premium collection began on June 01, 2000, and the first unemployment benefits were issued in March 2002. Since the establishment of unemployment insurance, allowances have been covered by an unemployment insurance fund consisting of employee, employer, and state premiums. 
With the establishment of the fund, at the beginning, only those who lost their jobs benefited from the fund, but with changes made in 2008, all unemployed individuals started to receive benefits. The continuous increase in the expense items in the fund is regularly criticized and discussed for the inability to effectively use the fund. In addition, the rising number of individuals who are no longer entitled to unemployment allowance is also criticized. In particular, the fund is perceived as not being effectively made available for the unemployed, resulting in calls for easing the conditions for receiving unemployment allowance.

Severance pay, which is another passive labor market policy with a history of approximately 130 years, is probably the most widely applied compensation or income support program in the world. The practice of providing severance pay, which emerged at the end of the 19th century, began to spread in Europe with the establishment of the International Labour Organization (ILO) in 1919 after World War I, and with the emergence and rise of welfare states, it gained broad application following World War II. Parallel to the practices of severance pay that started to become widespread in Europe, severance pay was first regulated in Turkey with the Labor Law No. 3008, which was enacted in 1936. Severance pay, which has been subject to many changes at different dates since its entry into force and has been in force to the present day, is compensation paid to the employee by an employer when an employment contract is terminated for reasons specified in the law, in the amount of 30 days' wage for each year of employment. However, for various reasons only a small portion of those who lose their jobs benefit from severance pay. Therefore, discussions regarding the creation of a fund system that is available to all employees who have lost their jobs and to save employers from sudden and burdensome payments, remains on the Turkish passive labor market policy agenda and constitutes one of the most discussed issues in working life.

Although the discussions regarding a severance pay fund intensified in the 1970s, the issue of funding was first raised in the 2nd Labor Assembly convened in 1954. On many different dates since then, the creation of a severance pay fund has been the subject of draft laws, and although it is noted that a fund will be established for severance payments in the provisional Article 6 of the Labor Law, its debate. In this study, regulations, including laws, draft laws, development plans and published literature and statistics were investigated as a reference to 
provide a comprehensive evaluation of ongoing discussions regarding the establishment of a severance pay fund in Turkey, which has been on the agenda for many years, offering an overview of various opinions, research, and suggestions in this direction, as the use of Turkish unemployment insurance fund falls outside of its aim.ect 


\title{
Türkiye'de Kıdem Tazminatı ve İşsizlik Sigortası İkileminde Fon Tartışmaları
}

\begin{abstract}
Kıdem Tazminatı
İş hukukuna özgü, iş̧̧inin işini kaybetme olgusuna ve kıdem esasına dayalı özel bir tazminat türü olan kıdem tazminatı, kanunda belirtilen asgari çalışma süresini dolduran işçinin hizmet akdinin, kanunda belirtilen nedenlerden biriyle son bulması durumunda işveren tarafından işçiye ya da işçinin ölmesi halinde mirasçılarına kıdemi ve ücreti dikkate alınarak ödenen bir tazminattır. (Süzek, 2008: 679).

Uluslararası Çalışma Örgütü’nün (ILO) 1982 yılında kabul etmiş olduğu ve 1994 yılında Türkiye tarafından da onaylanan 158 sayılı "Hizmet İlişkisine Son Verilmesi Sözleşmesi”nin 12. maddesinde kıdem tazminatı; "hizmet ilişkisine son verilen bir işçiye, çalışma süresi ve ücret düzeyine göre belirlenecek ve doğrudan işveren tarafından ya da işverenlerin katkısıyla oluşturulmuş bir fondan ödenen bir miktar para”, olarak tanımlanmıştır (ÇSGB, 1998: 432-433). Kıdem tazminatının amac1; işçinin bir işveren için çalıştığı süre zarfında işyerine yapmış olduğu katkısının, yıpranmasının, yeni bir iş buluncaya kadar yaşamış olduğu güçlüklerin ve geçmiş hizmetlerinin karşılığı olarak işçiye ödeme yapılmasıdır (Narmanlıoğlu, 1998: 332).

Kıdem tazminatının ilk ortaya çıkışı hakkında net bir bilgi olmamasına rağmen uygulamanın 19.yüzyılın sonlarında ortaya çıktığı ve 20.yüzyılın başlarından itibaren gelişim gösterdiği bilinmektedir. 1870 ve 80 'li yıllarda Fransa'da demiryolu sektöründe yaşanan büyük çaplı işten çıkarmalar kapsamında mahkemeye intikal eden çok sayıda demiryolu işten çıkarma davası sonucunda, işverenlerin tazminat ödemesine yönelik yargı kararları kıdem tazminatının başlangıç noktası olarak sayılabilir. Diğer yandan 1896 yılında Almanya'da Carl Zeiss kuruluşunda işten ayrılma tazminatı adı altında başlatılan uygulama da ilk kıdem tazminatı uygulaması olarak kabul edilmektedir (Holzmann vd., 2011: 6-7). I. Dünya Savaşı'ndan sonra ILO'nun da etkisiyle Avrupa'da yaygınlaşmaya başlayan kıdem tazminatı uygulaması, refah devletlerinin artış göstermesiyle birlikte II. Dünya Savaşı'ndan sonra geniş bir uygulama alanına kavuşmuştur.
\end{abstract}

Türkiye'de ise kıdem tazminatına yönelik ilk düzenlemeler 1926 yılında yürürlüğe giren Borçlar Kanunu kapsamında yapılmıştır. Kanun, kıdem 
tazminatına yönelik açık ve doğrudan bir düzenlemeye yer vermemesine rağmen, işveren tarafından yapılan haksız fesihlere karşı, işçilere tazminat ödenmesi hükmüne yer vermesi nedeniyle dolaylı da olsa kıdem tazminatının başlangıcını oluşturduğu söylenebilir. Kıdem tazminatı açık bir şekilde ve doğrudan ilk kez 1936 yılında uygulamaya konulan 3008 sayılı İş Kanunu ile birlikte Türk iş hukukuna girmiştir (Okay, 1975: 107-108).

\section{Türkiye'de Kıdem Tazminatının Tarihsel Gelişimi}

Cumhuriyetin ilanı ile birlikte Türkiye'de, sanayileşme çabalarına paralel olarak işçi ve işveren ilişkilerinin düzenlenmesi ve işçilerin iktisadi ve hukuki açıdan korunması amacıyla 1936 yılında 3008 sayılı İş Kanunu yürürlüğe girmiştir. Bu kanun ile birlikte çalışma hayatını düzenleyen hükümlerden bir tanesi de kıdem tazminatıdır. İş Kanunu'nun 13. maddesinde, hizmet akdinin feshinde en az 5 tam yıl kıdemi olan işçiye her yıl için 15 günlük ücret tutarında bir tazminatın ödenmesi belirtilmiştir. Ayrıca kanun, fesih sebebi ne olursa olsun 5 yıllık kıdemi bulunan her işçiye hizmet akdinin feshi durumunda tazminat ödenmesine yer vermişti (Özveri, 2005: 16).

1950 yılında yürürlüğe giren 5518 sayılı Kanun ${ }^{1}$ ile birlikte 3008 sayılı İş Kanununda yapılan değişiklikler kapsamında; işçinin kıdem tazminatına hak kazanabilmesi için hizmet akdinin feshinin hangi nedenlerle yapılabileceği düzenlenmiş ve feshin nedeni ne olursa olsun her fesihte tazminat alınabilmesinin önüne geçilmiştir. Diğer yandan 5 yıllık kıdem tazminatına hak kazanma süresi 3 yıla indirilmiş ve bu kıdem süresinde, aynı işverenin farklı işyerlerindeki hizmetlerinin toplamı dikkate alınmıştır. Aynı zamanda işyerinin devir ve intikali durumunda da işverenin sorumlulukları belirtilmiştir. 1952 yılında kabul edilen 5868 sayılı Kanun² ile birlikte, yaşlılık aylığı ve toptan ödeme almak maksadıyla hizmet akdini fesheden işçilerin de kıdem tazminatını alabilmesinin önü açılarak, işçiler lehine bir değişikliğe gidilmiştir (Limoncuoğlu, 2010: 45).

1967 yılına kadar yürürlükte kalan 3008 sayılı İş Kanunu, 931 sayılı İş Kanunu'nun kabul edilmesiyle birlikte yürürlükten kaldırılmıştır. 931 sayılı İş Kanununun 14. maddesinde; "hizmet akdinin işverenin ahlak ve iyi niyet

\footnotetext{
1 İş Kanununun Bazı Maddelerinin Değiştirilmesi Hakkında Kanun

2 İş Kanununun 5518 Sayılı Kanunla Tadil Edilen 13. Maddesinin 6. Fıkrasının Değiştirilmesi Hakkında Kanun
} 
kurallarına uymayan tutum ve davranışları dışında kalan nedenlerle işveren tarafından veya sağlık durumları nedeniyle ya da ahlak ve iyi niyet kurallarına uyulmaması gibi nedenlerle işçi tarafından veya muvazzaf askerlik dolayısıyla fesih halinde 3 yıldan fazla hizmette bulunması koşuluyla işe başladığından itibaren her bir tam yıl için işçiye 15 günlük ücreti tutarında bir tazminat verilir ve 6 aydan fazla süreler ise yıla tamamlanır" ifadelerine yer verilmiştir. 931 sayılı Kanun ile birlikte; kıdem hesabında 6 aydan fazla sürelerin yıla tamamlanması, sağlık nedeniyle işçinin iş sözleşmesini fesih etmesi halinde tazminata hak kazanması ve işçinin ölümü halinde kıdem tazminatının mirasçılarına ödenmesi şeklinde kıdem tazminatında değişiklikler yapılmıştır (Çelik, 2015: 32).

931 sayılı İş Kanunu'nun 1970 yılında Anayasa Mahkemesi tarafından iptal edilmesinden dolayı 1971 yılında 1475 sayılı İş Kanunu uygulamaya konulmuştur. Kanunun 14. maddesinde düzenlenen kıdem tazminatına yönelik 1927, 2320, 2457, 2762, 2869 ve 4447 sayılı kanunlar ile birlikte değişiklikler yapılarak kıdem tazminatı uygulaması günümüzdeki halini almıştır. 1975 yılında çıkarılan 1927 sayılı Kanun ${ }^{3}$ ile birlikte, kıdem tazminatına hak kazanabilmek için gerekli kıdem süresi 3 yıldan 1 yıla indirilmiş ve her geçen tam y1l için ödenecek kıdem tazminatı miktarı 15 günden 30 günlük ücret tutarına çıkarılmıştır. Bir yıldan arta kalan süreler için de kıdem tazminatı miktarının oranlanarak ödeme yapılacağı düzenlenmiş ve böylelikle 6 ayı geçen kıdem süresinin yıla tamamlanması uygulaması sona ermiştir. Diğer yandan kıdem tazminatına ilk kez tavan uygulaması getirilerek kıdem tazminatına esas olan 30 günlük ücret tutarının her yıl için dikkate alınacak miktarı, günlük asgari ücretin 30 günlük tutarının 7,5 katı ile sınırlandırılmışıtır. Ayrıca kanunda, kıdem tazminatına ilişkin bir fon kurulması da öngörülmüştür (Limon, 2015: 151-152).

1980 y1lında yürürlüğe giren 2320 sayılı Kanun ${ }^{4}$ ile birlikte, 1979 yılında Anayasa Mahkemesi tarafindan iptal edilen 1927 sayılı kanunun kıdem tazminatına tavan getiren hükmü yeniden düzenlenmiştir. Yine bu kanun

31475 Sayılı İș Kanununun Bazı Maddelerinin Değiștirilmesi ve 26. Maddesinin İkinci Fıkrasının Yürürlükten Kaldırılması, 193 Sayılı Gelir Vergisi Kanununun 25. Maddesinin 7. Fıkrasının Değişstirilmesi ve Bir Geçici Madde Eklenmesi Hakkında Kanun

41475 Sayılı İş Kanununun 1927 Sayılı Kanunla Değişik 14. Maddesinin Değiştirilmesi, 98. Maddesine Bir Fıkra Eklenmesi, 193 Sayılı Gelir Vergisi Kanununun 1927 Sayılı Kanunla Değişik 25. Maddesinin 7. Fıkrasının Değiștirilmesi ve 04.07.1975 Tarihli 1927 Sayılı Kanunun 6. Maddesinin Yürürlükten Kaldırılmasına Dair Kanun 
kapsamında yapılan bir düzenleme ile kıdem tazminatı konusunda kanun hükümlerine uyulmadığ 1 takdirde İş Kanununun 98. maddesine eklenen bir hükümle, 6 aydan 2 y1la kadar hapis ve 20 bin liradan 50 bin liraya kadar para cezası esası getirilmiştir. 1981 yılında yürürlüğe giren 2457 sayılı Kanun ${ }^{5}$ ile birlikte, kanun ile kurulu kurum ve kuruluşlarda çalışanların kıdem tazminatı niteliğindeki ödemelerinde de tavan uygulamasının esas alınacağı, aksi bir durumda ise 98. maddede belirtilen cezai yaptırımın uygulanacağı hükmüne yer verilmiştir (Uluğ, 2007: 51).

1982 yılında çıkarılan 2762 sayılı Kanun ${ }^{6}$ kapsamında yapılan değişiklikle, kıdem tazminatının üst sınırı belirlenmiş ve en yüksek devlet memuruna bir hizmet yılı için ödenecek azami emeklilik ikramiyesini geçemeyeceği şeklinde yeniden düzenlenmiştir. 1983 yılında yürürlüğe giren 2869 sayılı Kanun ${ }^{7}$ ile birlikte, kadın çalışanların evlendikleri tarihten itibaren 1 yıl içinde kendi istekleri ile işi bırakmaları halinde kıdem tazminatından yararlanmalarını sağlamaya yönelik düzenlemeye gidilmiştir. Ayrıca zamanında ödenmeyen kıdem tazminatı için ödenmeyen süreye ilişkin mevduata uygulanan en yüksek faizin ödenmesi esası yine bu kanun kapsamında yapılan değişikliklerden bir diğeridir. 1999 yılında kabul edilen 4447 sayılı İssizlik Sigortası Kanunu ile birlikte 1475 sayılı Kanunun 14. maddesi bugünkü halini almıştır. 4447 sayılı Kanun kapsamında 14. maddeye getirilen bir ek ile yaş haddini beklemeden prim ödeme gün sayısını dolduran çalışanların kendi iradeleriyle işten ayrılmaları durumunda da kıdem tazminatına hak kazanacakları ifade edilmiştir (Özveri, 2005: 17).

Çalışma hayatının değişen koşullarına uyum sağlayabilmek adına 2003 yılında 4857 sayılı İş Kanunu'nun yürürlüğe girmesiyle 1475 sayılı İş Kanunu mülga olmuştur. Yeni İş Kanunu'nda kıdem tazminatı ile ilgili bir düzenlemeye gidilmemiş, sadece Geçici 6. maddede kıdem tazminatına ilişkin bir fon kurulması öngörülmüştür. Aynı maddede kıdem tazminatı fonunun uygulamaya geçeceği tarihe kadar işçilerin kıdem tazminatları için 1475 sayılı İş Kanunu'nun 14. maddesinin uygulanmasına devam edileceği de belirtilmiştir (Tunçomağ ve Centel, 2016: 236).

5854 Sayılı Deniz İş Kanununun 20. Maddesi İle 1475 Sayılı İş Kanununun 14. Maddesinin Değiştirilmesi ve Bu Kanuna Bir Ek Madde İle 2319 ve 2320 Sayılı Kanunlara Geçici Maddeler Eklenmesi Hakkında Kanun

61475 Sayılı İş Kanununun 14. Maddesinin, 854 Sayılı Deniz İş Kanununun 20. Maddesinin Değiştirilmesi ve Bu Kanunlara Bir Ek Geçici Madde Eklenmesi Hakkında Kanun

71475 Sayılı İş Kanununun Bazı Maddelerinin Değiştirilmesi ve Bu Kanuna İki Geçici Madde Eklenmesi Hakkında Kanun 


\section{Kıdem Tazminatının Hukuki Niteliği ve İşlevleri}

Kıdem tazminatının hukuki niteliği konusunda iş hukuku öğretisinde çok sayıda farklı görüşe rastlamak mümkündür. Bunlar; ileriye bırakılmış ücret, ikramiye, tazminat, işçinin işyerine bağl1lı̆̆ının bir karşılığ 1 , işçinin yıpranmasının karşılığı, işsizlik sigortası, iş güvencesi, kendine özgü bir müessese şeklinde savunulan görüşlerdir (Süzek, 2008: 679-680). Kıdem tazminatını çalışanın işyerinde hizmetinin karşılığı ve ödenmesi belirli şartların gerçekleşmesine bağlı olarak sonraya bırakılmış bir ücret olarak savunanlara göre, emeğini işverene sunan işçi karşılığında alacağı ücretinin bir bölümünü düzenli bir şekilde "ücret” adı altında alırken, geriye kalan bölümünü de hak etmesi şartıyla "kıdem tazminatı" adı altında geciktirilmiş ve toplu olarak almaktadır. Ücret, işçinin ve bakmakla yükümlü olduğu ailesinin geçimini sağlarken, kıdem tazminatı ise işçinin karşılaşabileceği riskler karşısında sağlanan bir güvence olduğu ifade edilmektedir (Balc1 ve Ersöz, 1997: 26; Çelik, 2015: 30).

İkramiye görüşüne göre kıdem tazminatı; çalışanın uzun süre hizmette bulunduğu işyerinden ayrılırken sadakat ve bağlılıkla çalışması karşılığında işveren tarafindan ödüllendirilmesidir. Bu görüş, 3008 sayılı İş Kanunu kapsamında kıdem tazminatına hak kazanabilmek için 5 yıllık kıdem şartının aranması ve fesih sınırlamasının bulunmamasından dolayı yoğunluk kazanmış ve o dönem içerisinde Yargitay tarafından da kabul görmüştür. Ancak 1950 yılında 5518 sayılı Kanun ile 3008 sayılı İş Kanununda yapılan değişikliklerle birlikte kıdem tazminatına hak kazanabilmek için iş sözleşmesinin feshinin hangi sebeplerle yapılabileceğinin düzenlenmesi ve kıdem süresinin üç yıla indirilmesi bu görüşü olumsuz şekilde etkilemiştir. Aynı zamanda 5518 sayılı Kanun ile birlikte yapılan değişikliğin gerekçesinde, kıdem tazminatının işçilerin yıpranmasının karşılığg olduğu görüşüne de yer verilmiştir. Daha sonra 1975 yılında 1927 sayılı Kanun ile 1475 sayılı İş Kanununda yapılan değişiklikle birlikte kıdem süresinin üç yıldan bir yıla indirilmesi ikramiye görüşünün değerini yitirmesine neden olmuştur (Başterzi, 1996: 207; Çelik, 2015: 30).

Kıdem tazminatının hukuki niteliği konusunda belirtilen görüşlerden biri de, iş sözleşmesi sona eren işçilerin işsiz kalması nedeniyle maruz kaldıkları gelir kayıplarını belli düzeyde telafi etmeyi hedefleyen işsizlik sigortası olduğu görüşüdür. 1936 yılında yürürlüğe giren 3008 sayılı İş Kanunu'nun gerekçesinde, Türkiye'de ihtiyarlık ve işsizlik sigortasının olmaması nedeniyle, bu sigorta 
kollarının kurulmasına kadar bu kişilere kıdem tazminatı ödemesi yapılmasının gerektiği savunulmuştur. 1967 yılında kabul edilen 931 sayılı İş Kanunu'nun gerekçesinde de "kıdem tazminatı uygulamasının çalışma hayatına ilişkin sakıncaları yönünde yapılan çeşitli itirazlar dikkate alınmakla birlikte, bu hakkın kaldırılmasının kazanılmış haklar açısından sakıncaları göz önüne alınarak ve henüz işsizlik sigortasının da oluşturulmadığından hareketle bu konunun sözü geçen sigortanın kuruluşu sırasında yeniden görüşülmesi münasip bulunmuştur” ifadesi yer almıştır. Nitekim Yargıtay da 1965 tarihli bir kararında, kıdem tazminatının işsizlik sigortası niteliğinde olduğunu belirtmiştir (Limoncuoğlu, 2010: 46).

Türkiye'de 1968 yılında işsizlik sigortasının kurulması için başlatılan çalışma kapsamında hazırlanan İşsizlik Sigortası Kanun Tasarısı'nda da kıdem tazminatının kaldırılması öngörülmüştür. Türkiye İşçi Sendikaları Konfederasyonu (TÜRK-İŞ) ise kıdem tazminatının kaldırılması girişimlerine karşı çıkmış ve işsizlik sigortasının iş güvencesi için yeterli olmayacağını, kıdem tazminatı uygulamasının devam etmesi gerektiğini savunmuştur. Dolayısıyla, 1960'lı yılların başlarından, 931 sayılı İş Kanunu'nun Anayasa Mahkemesi tarafından iptal edilmesiyle birlikte 1475 sayılı Kanun'un hazırlanmasına kadar geçen sürede kıdem tazminatı uygulamasının işsizlik sigortası yerine ikame edildiği yasal düzenlemelerde açıkça yer almıştır (Tunçomağ ve Centel, 2016: 236).

Kıdem tazminatının niteliği konusundaki görüşlerden biri olan tazminat görüşüne göre kıdem tazminatı; çalışanın işyerinde yıpranması ve işini kaybetmesine karşılık işveren tarafından çalışana ödenen bir tazminattır. Özellikle 1940 ve 50'li yıllarda Yargıtay'ın vermiş olduğu kararlarında bu görüşü destekledikleri görülmektedir. Aynı zamanda 1966 yılında Türkiye Odalar ve Borsalar Birliği (TOBB) tarafından yapılan bir çalışmada da kıdem tazminatının niteliği kapsamında tazminat görüşü benimsenmiştir (Limoncuoğlu, 2010: 46). 1975 yılında yürürlüğe giren ve kıdem tazminatında önemli değişiklikler yapan 1927 sayılı Kanunun gerekçesinde de kıdem tazminatının maddi bir güvence sağlamasının yanında iş güvencesi de sağladığı ve dolayısıyla sendikal yapılara katkıda bulunduğuna işaret edilmektedir. Kanun gerekçesinde "kıdem tazminatı uygulamasının çalışanların gelir ve iş güvenliğini sağlayıcı ve keyfi olarak işten çıkarma durumunun işçi aleyhine ortaya çıkardığı sonuçları giderici niteliğiyle birlikte, 
emniyetli ve hakiki hüviyetli bir sendikalaşma hareketine yardımcı ve hatta katkıda bulunabileceği kabul edilen bir gerçektir" görüşüne yer verilmiştir. Bu görüşü savunan TÜRK-İş de, kıdem tazminatının işçinin emniyetini sağlayan ve işten çıkarılma korkusundan uzak bir şekilde çalışmasını sağlayan bir müessese olduğuna vurgu yapmaktadır (Çelik, 2015: 31).

Türkiye'de 1999 yılında 4447 Sayılı İşsizlik Sigortası Kanunu ve 2002 yılında da 4773 Sayılı İş Güvencesi Kanununun yürürlüğe girmesiyle birlikte kıdem tazminatının tek bir işleve indirgenemeyen ve birden fazla işlevi ve niteliği bulunan, işçinin işinde sabır ve sadakatle geçirdiği kıdeminin ve yıpranmasının karşılığı olan özgün bir işçi hakkı olarak nitelendirilmesinin daha gerçekçi olacağı söylenebilir.

Kıdem tazminatının niteliğine ilişkin bir diğer görüş ise, kendi kendine özgü bir müessese olduğu görüşüdür. Kıdem tazminatının hukuki niteliğine yönelik ileri sürülen görüşlerin tek başlarına kıdem tazminatını açıklamada yetersiz kaldığg dolayısıyla bu görüşlerin hepsini belirli ölçülerde bünyesinde barındıran ve hepsinden esinlenen kıdem tazminat, belirli bir kalıba sokulamayan kendine özgü bir kurum niteliğine dönüşmüş bulunmaktadır (Çelik, 2007: 289).

\section{Kıdem Tazminatına Hak Kazanma Koşulları ve Tazminatın Miktarı}

İşçilerin kıdem tazminatına hak kazanabilmeleri için öncelikle iş kanunlarına tabi olarak sürekli bir işte çalışmaları gerekmektedir. Diğer bir ifadeyle iş sözleşmesiyle çalışanların tamamı kıdem tazminatı talep edemez. Süreksiz bir işte çalışanlar (İş K. m. 10) ile İş Kanunu'nun 4. maddesinde ${ }^{8}$ belirtilen işlerde çalışanlar kıdem tazminatından yararlanamamaktadır. Diğer yandan Deniz İş Kanunu (m. 20) ile Basın İş Kanunu (m. 6) hükümlerine tabi olarak çalışan işçiler de kıdem tazminatından yararlanabilmektedir (Tunçomağ ve Centel, 2016: 237).

İş Kanunu'na tabi olarak çalışan işçinin iş sözleşmesinin kanunda belirtilen durumlardan biri ile feshedilmesi, işçinin en az bir yıl kıdeminin bulunması ve işçinin ölümü halinde işçi kıdeme hak kazanabilmektedir. Ancak burada iş

8 Deniz ve hava taşıma işlerinde, 50’den az işçi çalıştırılan (50 dâhil) tarım ve orman işlerinin yapıldığ işyerlerinde veya işletmelerinde, aile ekonomisi sınırları içinde kalan tarımla ilgili her çeşit yapı işleri, bir ailenin üyeleri ve 3. dereceye kadar (3. derece dâhil) hısımları arasında dışardan başka biri katılmayarak evlerde ve el sanatlarının yapıldığı işlerde, ev hizmetlerinde, çıraklar hakkında, sporcular hakkında, rehabilite edilenler hakkında, 507 sayılı Esnaf ve Sanatkârlar Kanunu'nun 2. maddesinin tarifine uygun üç kişinin çalıştığ işyerlerinde İş Kanunu hükümleri uygulanmaz. 
sözleşmesinin feshi konusu üzerinde durulması gerekmektedir. Çünkü kıdem tazminatı hakkının ortaya çıkmasında iş sözleşmesinin işçi veya işveren tarafından feshedilmesi ve hangi nedenlerle feshin yapıldığına göre farklılıklar söz konusu olmaktadır.

İşveren, iş sözleşmesini İş Kanunu'nun 17. maddesine (süreli fesih) göre, fesih bildirim süresi vererek ya da bu sürelere ilişkin ücreti peşin ödeyerek ya da ihbar tazminatı ödemekle yükümlü olarak feshettiğinde, en az bir yıl kıdemi olan işçi kıdem tazminatı almaya hak kazanır. İşveren, İş Kanunu'nun 25. maddesinde belirtilen haklı nedenlerden dolayı sözleşmeyi derhal feshedebilir. Bu durumda sadece işçinin ahlak ve iyi niyet kurallarına uymayan halleri (m. 25/II) nedeniyle işveren tarafından yapılan fesihlerde işçi kıdem tazminatı talep edemez. Ancak sağlık nedenleri (m. 25/I), zorlayıcı nedenler (m. 25/III) ve tutuklanma (m. 25/ IV) nedeniyle işveren tarafından sözleşmenin derhal feshedilmesi halinde işçi kıdem tazminatı almaya hak kazanır (Şakar, 2016: 212).

İşçi, iş sözleşmesini İş Kanunu'nun 17. maddesine göre bildirimli fesihle sona erdirmesi halinde kıdem tazminatına hak kazanamaz. Ancak bu maddeye göre işçi tarafından yapılan feshin bazı istisnai durumları vardır. Bunlar; işçinin iş sözleşmesini muvazzaf askerlik hizmeti nedeniyle sona erdirmesi, kanunla kurulmuş kurum veya sendikalardan yaşl1lık, emeklilik ya da malullük aylığı veya toptan ödeme almak amacıyla sona erdirmesi ve kadın işçinin evlendiği tarihten itibaren bir y1l içinde kendi isteğiyle iş sözleşmesini sona erdirmesi halinde kıdem tazminatı hakkı doğmaktadır. Bunun yanında İş Kanunu'nun 24. maddesinde belirtilen ahlak ve iyi niyet kurallarına uymayan haller, sağlık nedenleri ve zorlayıcı nedenler ile işçinin iş sözleşmesini haklı nedenle derhal fesih etmesi durumunda işçi kıdem tazminatına hak kazanmaktadır. İşçinin ölümü halinde ise en az bir yıl kıdemi olması şartıyla yasal mirasçıları kıdem tazminatı talep edebilmektedir (Aktay vd., 2006: 221-222).

Kıdem tazminatının miktarı, işçinin işe başladığı tarihten itibaren her geçen tam yıl için 30 günlük ücret tutarıdır. Esas alınacak bu ücret işçinin fiilen eline geçen ücreti değil de brüt ücreti ve son almış olduğu ücretinin üzerinden hesaplanmaktadır. Ayrıca kıdem tazminatına esas olacak ücretin hesabında, ilaveten işçiye sağlanmış olan para ve para ile ölçülmesi mümkün akdi ve kanundan doğan menfaatler de dikkate alınır. İşçiye bir yıldan artan süreler için de aynı oran üzerinden ödeme yapılmaktadır. Diğer yandan kıdem 
tazminatının bir üst sınırı ya da bir tavan miktarı ${ }^{9}$ bulunmaktadır. Buna göre işçiye her yıl için ödenecek kıdem tazminatı, 657 sayılı Devlet Memurları Kanunu'na tabi en yüksek dereceli devlet memurunun (Başbakanlık Müsteşarı) bir yıl için alacağı emekli ikramiyesini geçemez. Kıdem tazminatının zamanında ödenmemesi durumunda, açılacak davanın sonunda hâkim gecikme süresi için, ödenmeyen süreye ilişkin mevduata uygulanan en yüksek faizin ödenmesine karar verir (Sümer, 2010: 269-273). Ayrıca kıdem tazminatı için 10 yıllık olan zamanaşımı süresi, 25 Ekim 2017 tarihinde yürürlüğe giren 7036 Sayılı İş Mahkemeleri Kanunu ile birlikte değiştirilmiştir. Kanunun 15. maddesi ile 4857 Sayılı İş Kanunu'na zaman aşımı konusunda Ek 3. Madde eklenmiş ve buna istinaden kıdem tazminatı zamanaşımı süresi 5 yıl olarak belirlenmiştir.

\section{Kıdem Tazminatı Uygulamasında Ortaya Çıkan Sorunlar}

İş sözleşmesinin sona ermesiyle doğan kıdem tazminatı hakkı; hem işverenler, hem işçiler hem de çalışma barışı ve ülke ekonomisi açısından bir takım sorunların ortaya çıkmasına neden olmaktadır. Kıdem tazminatı yükümlülüğü en başta işyerleri açısından ciddi bir maliyet unsuru oluşturmaktadır. Özellikle ekonomik kriz ve daralma dönemlerinde işçi çıkarmak mecburiyetinde olan işyerlerinin ödemek zorunda kaldıkları kıdem tazminatı borçları, işverenlerin konjonktürel dalgalanmalara karşı esnekliklerini zayıflatarak hareket kabiliyetlerini sınırlandırmakta ve krizlerden daha fazla etkilenmelerine neden olmaktadir.

Kıdem tazminatı yükü arttıkça işverenler bu yükümlülükten kurtulabilmek için çeşitli yollara başvurmaktadır. İşverenlerin kıdemli işçiler yerine sıklıkla daha düşük ücretlerden yeni işçi alımına gitmeleri, kıdemi artan işçilerin tazminatı düşünülerek işten ayrılmaları için ücretlerinin düşük tutulması (kıdem tazminatına esas ücretin son ücret olması), yeni işe alınan işçilerin işine bir yıl dolmadan son verilmesi, işçilerin istifaya zorlanması ya da kayıt dışı çalıştırma, iş sözleşmesinin ahlak ya da iyi niyet kurallarına uyulmamış gibi gösterilerek feshedilmesi, işyerinin hileli yollarla ödeme gücü olmayan kişilere devredilmesi, iş sözleşmelerinin belirli süreli yapılarak işçilerin kıdeme hak kazanmadan kendiliğinden sona ermesi, işyerindeki asıl işlerin çok sayıda alt işveren arasında

9 Tavan miktarı, 1 Ocak ve 1 Temmuz tarihlerinde memur maaşlarına zam yapıldıkça artmaktadır. 01 Ocak30 Haziran 2021 tarihleri arasında kıdem tazminatı tavan miktarı 7.638,96 TL olarak belirlenmiştir (TC. Aile, Çalışma ve Sosyal Hizmetler Bakanlığı, https://ailevecalisma.gov.tr/tr-tr/istatistikler/calisma-hayatiistatistikleri/kidem-tazminati/kidem-tazminati-tavan-miktari/, 25.03.2021) 
paylaştırılarak kanuni yükümlülükten kurtulma çabaları bu yollardan yalnızca birkaçını oluşturmaktadır (Kutal, 2009: 6).

Kıdem tazminatı alacaklarının tahsilinde ortaya çıkan güçlükler işçilerin yarg1 yoluna başvurmasına neden olmakta ancak yavaş ilerleyen ve aylar süren yargı süreci ve işçilerin bu süreci başlatmasına engel olan bazı durumlar (zorla ibraname imzalatılması, maddi yardımların yapılması, tanıdık vasıtasıyla işe girmiş olduğundan dolayı mahcubiyetin olması vb.) işçileri bu yoldan alıkoymaktadır (Doğan ve Yıldırım, 2016: 22-23). Özellikle kıdem tazminatı alacaklarının ücret niteliğinde olmaması nedeniyle öncelikli alacaklar arasında yer almamasından dolayı yargı yoluna başvuran ve uzun süren çabaların sonucunda davayı kazanan işçiler, iflas eden işverenin diğer alacakları arasında kendine yer bulamamaktadır. Diğer bir ifadeyle, devlet alacakları, rehinli alacaklılar, bankalar ve ücret alacaklarından sonra kıdem tazminatı almaya hak kazanan işçi, tazminatını ya hiç alamamakta ya da çok az bir kısmını alabilmektedir (Kutal, 2009: 6).

Diğer yandan işinden memnun olmayıp (ücret düşüklüğü, olumsuz çalışma koşulları vb. nedenler) başka bir iş arayan çalışanlar kıdem tazminatlarını alabilmek için işinden ayrılamamakta veya istifa ederek tazminat hakkını kaybetmektedirler. Kıdem tazminatı hakkını kaybetmemek için işini değiştiremeyen ve mevcut işlerinde çalışmaya devam etmek zorunda olan işçiler arasında verimlilik kaybı ortaya çıkabilmekte ve dolayısıyla da eksik istihdam artışı yaşanabilmektedir. Aynı zamanda bu durum emek mobilitesini de zayıflatan bir etkiye sahip olmakta ve bireylerin özgürce işini seçme hakkının elinden alınmasına neden olmaktadır.

İşverenlerin kıdem tazminatı yükümlülüğünden kurtulabilmek için en çok başvurdukları yöntemlerin başında, işçilerin bir yılını doldurmadan işten çıkartılarak yenilerinin işe alınması yöntemidir. Bu uygulama bir taraftan işçi devrini hızlandırırken diğer taraftan çalışma barışını olumsuz olarak etkilemektedir. Ayrıca kıdem tazminatı yükümlülüğü işletmelerin yatırım kararlarını etkileyerek ekonomik gelişmeyi dolayısıyla da istihdamı olumsuz yönde etkilemektedir. Kıdem tazminatı nedeniyle olumsuz yönde etkilenen istihdam artışı bir yandan kayıt dışı istihdamı teşvik ederken diğer yandan işletmelerin, ekonominin genişleme dönemlerinde dahi yeni işçi alımını mümkün olduğunca ertelemesine ve fazla mesaiye ağırlık vermesine neden olmaktadır (Güner vd., 2016: 33). 
2016 yılında Çalışma ve Sosyal Güvenlik Bakanı Süleyman Soylu’nun kıdem tazminatıyla ilgili yapmış olduğu açıklamalarda, her 100 kişiden ancak 14'ünün kıdem tazminatını alabilme fırsatına sahip olduğunu, 86'sının ise kıdem tazminatı alamadığını ifade etmiştir. Aynı yılda Başbakan yardımcısı Mehmet Şimşek' in yaptığı açıklamalarda, özel sektörde çalışan işçilerin \%90'ına yakınının kıdem tazminatlarını alamadığını belirtmiştir. Ayrıca Şimşek, açıklamalarının devamında Türkiye'nin dünyada kıdem tazminatının yüksek olduğu ülkeler arasında yer aldığına ve bu durumun da işgücü piyasasını katı hale getirdiğine vurgu yapmıştır (Sabah Gazetesi, 2016). 2017 yılında ise dönemin Çalışma ve Sosyal Güvenlik Bakanı olan Mehmet Müezzinoğlu yapmış olduğu açıklamalarda, çalışanların \%70’inin kıdem tazminatından yararlanamadığını belirtmiştir (Anadolu Ajansı, 2017). İstihdam Koruma Mevzuatı Endeksinin hesaplanmasında yararlanılan kıdem tazminatı verilerine göre Türkiye, OECD ülkeleri arasında Portekiz ile birlikte en yüksek seviyede kıdem tazminatı ödemesini zorunlu tutan ülkeler arasında yer almaktadır (ÇSGBa, 2015: 32). Ayrıca 2018 yılı İş Yapma Kolaylığı Raporu'nda Türkiye'nin, en yüksek kıdem tazminatı düzeyine sahip ilk 32 ülke arasında bulunduğu belirtilmektedir. (World Bank Group, 2018: 208-221).

Çalışma Genel Müdürlüğü'nün yapmış olduğu araştırmaya göre, işverenlerin \%49'u kıdem tazminatı ödememek için çalışanlarına bir yılı doldurmadan işe giriş-çıkış yaptırdığı sonucuna varılmıştır. Araştırmada kıdem tazminatında en ciddi sorunun sanayi sektöründe yaşandığ 1 ifade edilmektedir. Kıdem tazminatını alamayan veya eksik alanların \%96'sından fazlasının dava açmaktan kaçındığg ve çalışanların \%42'sinin de kıdem tazminatı hakkını kaybetmemek için iyi koşullarda yeni iş tekliflerini geri çevirdiği araştırmada yer almaktadır. Aynı araştırmada işverenlerin de \%77,6'sı mevcut uygulamadan şikâyetçi olduğunu, $\% 75$ 'i ise tek seferde ve toptan ödemenin finansal yönden kendilerini zorladığını belirtmektedir (Milliyet, 2020)

Diğer yandan İŞKUR iş başvurusunda bulunanlara yönelik yapmış olduğu kıdem tazminatı araştırmasında, katılımcıların \%78,6'sının işine son verildiği, $\% 21,5$ 'inin istifa ettiği ve \%57'sinin ise k1dem tazminatını alamadığ belirtilmektedir. Araştırmada iş arayan gençlerin çoğunluğunun mevcut kıdem tazminatı uygulamasından memnun olmadığına ve mevcut sistemin değiştirilmesi ihtiyacına vurgu yapılmaktadır. Ayrıca araştırma, kıdem tazminatını almada sendikalı olmanın da bir farklılık yaratmadı̆̆ını 
göstermektedir. Buna göre, sendikaya üye olan çalışanların \%51,9'u tazminat alamamış, \%35,8'i tazminatının tamamını almış ve \%12,3'ü ise bir kısmını alabilmiştir. Araştırmaya göre çalışanların \%42'sinden fazlasının kıdem tazminatını haklarını kaybetmemek adına yeni iş tekliflerine olumsuz geri dönüş yaptıkları ifade edilmektedir (Milliyet, 2020).

2016 yılında Yıldız ve Akçay'ın, Türkiye'de kıdem tazminatının ödenmeme nedenlerine yönelik yapmış oldukları çalışmada, katılımcıların \%51,4'ü kıdem tazminatını alamadığını, \%8,7'si bir kısmını alabildiğini ve \%39,9'u ise kıdem tazminatının tamamını aldığını belirtmiştir. Kıdem tazminatı alamayanların tazminat alamama nedenlerine bakıldığında, katılımcıların \%19,1'inin istifa ettiği, \%6,4'ü işyerinin iflas ettiği ve \%35,6's1 ise işverenlerin haksız olarak kıdem tazminatlarını vermediği görülmektedir. Kıdem tazminatını alamayanlar ile eksik alanların \%85,5'i tazminat alacakları için dava açmadı̆̆ını, \%14,5'i ise dava açtığını ifade etmiştir. Çalışmada dava açmayanlarının dava açmama nedenlerine bakıldığında ise \%25,9'unun işverenin kendilerine zorla ya da hile ile istifa dilekçesi ya da hiçbir alacağının olmadığına dair ibraname imzalattı̆̆ı, \%22,8'i nasıl dava açılacağını bilmediği ve \%33,3'ü ise işvereni şikâyet etmek istememesi nedeniyle dava açmadıkları görülmektedir. Yine çalışmada sendikalı çalışanlar da kıdem tazminatlarını alamadıklarını ifade etmişılerdir. Ayrıca yapılan çalışmada kıdem tazminatının alınabilmesi durumu ile mevcut kıdem tazminatı uygulamasının değiştirilmesi isteği arasında anlamlı bir ilişkinin olduğu ve kıdem tazminatını eksik alan veya hiç alamayanların büyük bir çoğunluğunun mevcut uygulamanın değiştirilmesini istediği sonucu ortaya çıkmıştır (Yıldız ve Akçay, 2016: 755-763).

\section{Kıdem Tazminatı Fonunun Oluşturulması Kapsamında Çalışmalar}

Fon oluşturulması yönündeki çalışmalar geçmişten günümüze hala daha devam etmekte ve güncelliğini korumaktadır. 1950'li yıllarda başlayan fon tartışmaları yaklaşık 70 yıldır sürmekte olup bu konuda henüz somut bir adım atılamamıştır. Kıdem tazminatı fonunun oluşturulmasına yönelik çalışmalar 1970'li yıllarda yoğunlaşmış ve bu yönde ilk kanun tasarısı 1976 yılında hazırlanmıştır. Bu yıldan günümüze 45 yıllık bir süreçte yaklaşı 10 kanun tasarısı hazırlanmasına rağmen bu tasarılar yasalaştırılamamış ve uygulamaya geçirilememiştir. 
Kıdem tazminatı fonu konusu ilk olarak 1952 yılında yapılan II. Çalışma Meclisi'nde gündeme gelmiştir ve kıdem hakkına karş1lık gelen ödeneklerin işyerlerinde ayrı bir fon halinde ya da genel bir fonda toplanmasına yönelik şartların Çalışma Bakanlığı tarafından araştırılması kararına varılmıştır. Fon konusundaki bu girişim 1962 yılında toplanan III. Çalışma Meclisi'nde daha da olgunlaştırılarak, kıdem tazminatı uygulamasının işverenler tarafindan prim ödenmesi yoluyla işçi sigortaları kurumunun görevleri arasında sayılması temennisinde bulunulmuştur (Baydere, 1966: 219). Ayrıca 1961 yılında basın mesleğinde çalışanlara ilişskin uygulamaya konulan 212 Sayılı Basın İş Kanunu ile gazetecilerin kıdem tazminatı miktarları 15 günden 30 güne yükseltilmesine istinaden gazete işverenleri, bu tazminatın kurulacak bir fon aracılığıyla ödenmesini talep etmişlerdir. (Kaya, 2005: 181).

II. ve III. Çalışma Meclisi toplantılarında fonla ilgili girişimlerden sonra hükümet, fonun kurulmasından ziyade kıdem tazminatı müessesesinin kaldırılmasına yönelik bir girişimde bulunmuştur. 1968 yılında işsizlik sigortası kanun taslağı hazırlanmış ve çalışılmış sürelerin korunması kaydıyla kıdem tazminatı uygulamasının tamamen kaldırılması öngörülmüştür. Ancak işçi sendikalarından bu taslağa yönelik fon önerilerine gelen tepkilerden daha sert tepkiler gelmesi nedeniyle hükümet tasarıyı meclise göndermeden geri çekmiştir (Şakar, 2016: 17).

Kıdem tazminatıyla ilgili yasal girişimler esas itibariyle 1975 yılından sonra başlamış ve bu yılda 1927 sayılı kanun ile kıdem tazminatı işçi lehine genişletilmiştir. İşverenlerden gelen yoğun tepkiler üzerine kıdem tazminatına ilişkin bir tavan konulması ve fon kurulması ve bu fonun yaşlılık, emeklilik, malullük, ölüm ve toptan ödeme hallerine özgü olması ve fonun kurulmasının yasayla düzenleneceği kararlaştırılmıştır. 1976 yılında Çalışma Bakanlığı bünyesinde kıdem tazminatı fonunun kurulmasını öngören "k1dem tazminatı fonu kanun tasarısı taslăğı" hazırlanmıştır. Ayrıca bu taslak 1978 yılında hazırlanan iş güvencesi kanun tasarısı ile ilişkili hale getirilmesi de istenmiştir. Tasarı gerekçesinde fonun kurulmasıyla birlikte işçilerin, işyerlerinde iş güvencesine kavuşacağı ve işverenlerin de beklenmedik ve yüklü tazminatlardan kurtulacağ 1 ifade edilmektedir. Fon tasarısında işçi adına fona yatırılacak olan kıdem tazminatının işçinin son ücreti üzerinden hesaplanması ve işverenin fona ödeyeceği prim oranının da işçinin aylık ücret tutarının \%10'u olması öngörülmüştür (Nurdoğan vd., 2016: 1159). 
1976 yılında hazırlanan fon taslağında, fonun yönetiminde işçi ve işveren taraflarının da yer alması gibi bazı değişikliklere gidilerek 1980 yılında yeni bir kanun tasarısı hazırlanmıştır. 1982 yılında kıdem tazminatı fonu hükümlerine de yer veren yeni bir iş güvencesi kanun tasarısı gündeme gelmiş ve yine kıdem tazminatı ile ilişkilendirilmiştir. 1984 yılında ise, 1976 yılında hazırlanan kanun taslağ gündem maddesi olarak VII. Çalışma Meclisi'nde tartışılmıştır. Daha sonra 1991 yılında iş güvencesi ile işsizlik sigortası yasa taslağı ve 1992 yılında ise kıdem tazminatı fonu sandığı adı altında farklı bir taslak çalışması başlatılmıştır. Ancak bu girişimler, tarafların konuya farklı yaklaşımlarının ve kaygılarının olması nedeniyle başarısızlıkla sonuçlanmıştır (Şakar, 2016: 17-18).

2002 yılında 4857 Sayılı İş Kanunu'nun hazırlanması sırasında Bilim Kurulu iş kanunuyla birlikte kıdem tazminatı fonuna ilişkin bir yasa tasarısı taslak metni de hazırlamış ancak bu tasarı uzun tartışmalar sonucunda bir anlaşmaya varılamadığından yasalaştırılamamıştır. 2004 yılında gerçekleştirilen IX. Çalışma Meclisi toplantısında 2002 yılında oluşturulan taslak metni tekrardan ele alınarak müzakere edilmiş ancak herhangi bir sonuca varılamamıştır. Bugüne kadar yapılan kıdem tazminatı fonu çalışmaları içerisinde en ciddi çalışma olan bu tasarıya göre kıdem tazminatına, bağlı bulundukları kurum ve sandıklardan malullük, yaşlılık veya emeklilik aylığı yahut toptan ödeme almak maksadıyla iş sözleşmesini fesheden veya iş sözleşmesi işveren tarafından herhangi bir biçimde feshedilip de malullük, yaşlılık, emeklilik aylığı veya toptan ödeme almak amacıyla kurum ya da sandıklara müracaat edenler ile işçinin ölümü durumunda mirasçıları hak kazanacaktır (ÇSGB, ty., 9).

Bakanlık bünyesinde oluşturulması planlanan ancak idari ve mali yönden özerk olacağı belirtilen fondan, en az 10 yıl prim ödenmesi koşuluyla işçinin talebine istinaden kıdem tazminatının alınabileceği de belirtilmiştir. Ayrıca tasarıda fonun uygulamaya konulmasına kadar işçilerin kazanılmış haklarının korunacağı, uygulamaya konulduktan sonra ilk kez işe girenlerin ise yalnızca fon kapsamına alınacağı ifade edilmiştir. İşverenlerin her çalışan için aylık brüt ücretinin \%3’ü oranında prim ödeyeceği ve işçiye veya işçinin ölümü durumunda mirasçılarına fona prim ödenmiş olan her tam yıl için prim hesabına esas olan ücretin 30 günü tutarında kıdem tazminatının ödeneceği tasarıda öngörülmektedir. Aynı zamanda tasarıda bir yıldan artan süreler için ya da toplam prim ödeme 
süresi bir yıldan daha az olanlar için de aynı oran üzerinden ödeme yapılacağı ifade edilmektedir (ÇSGB, ty., 7-10).

Kıdem tazminatı fonu çalışmaları 2008 yılında tekrardan gündeme gelmiş ve bu yılın ilk aylarında hazırlanan "İş Kanunu ve Bazı Kanunlarda Değişiklik Yapılması Hakkında Kanun Tasarısı Taslağı” diğer adıyla "İstihdam Paketi” içerisinde ele alınmıştır (Koç, 2020). 2012 yılında ise "Kıdem Tazminatının İşçinin Bireysel Hesabına Yatırılması Hakkında Kanun Taslağı” hazırlanmıştır. Bu oluşturulan yeni fon modeli 2013 yılında gözden geçirilerek "Orta Vadeli Program" $1{ }^{10}$ hedefleri arasında da yer almıştır. Aynı zamanda kıdem tazminatı fon çalışmaları Ulusal İstihdam Stratejisi'nin (UİS) 2014-2016 yıllarını kapsayan eylem planları içerisinde de yer alarak, "tüm işçilerin erişebilirliğini güvence altına alan bir kıdem tazminatı reformu yapılacağı ve bireysel hesaba dayalı kıdem tazminatı fonu kurulacağı" ifadesi planda belirtilmiştir (ÇSGB, 2014: 15).

$\mathrm{Bu}$ yeni taslakta; işçinin prime esas aylık brüt kazancının \%4'ünün kıdem primi olarak Emeklilik Gözetim Merkezi adına açılacak hesaba yatırılacağı ve işverenlerden alınan kıdem primlerinin şirketler tarafından kurulan fonlarda yatırıma yönlendirileceği, kıdem primlerinin yatırılacağı şirket seçiminin işveren, bu primlerin değerlendirileceği fonların seçiminin ise işçi tarafından yapılacağı belirtilmiştir. Ayrıca tasarıda işsizlik sigortası prim oranı işverenlerde ve devlette binde beşe düşürülmüş ve kıdem tazminatına hak kazanabilmek için işçilerin 15 yıl sigortalılık süresini doldurmaları ve adlarına 3600 prim ödeme gün sayısı tahakkuk ettirilmesi gerektiği ifade edilmiştir. Bunlara ek olarak işçinin, konut edinmesi koşuluyla adına açılan bireysel kıdem hesabında biriken tutarın yarısını çekmeye, bireysel kıdem hesabına 5 yıl boyunca kıdem primi tahakkuk ettirilmemesi ve işçinin ölümü durumunda kanuni mirasçıları bireysel kıdem hesabında biriken tutarın tamamını çekmeye hak kazanacağı taslakta yer almaktadir (https://www.petrol-is.org.tr/sites/default/files/kt. yenitaslak.7.12.doc, 15.11.2020)

2013 yılında gerçekleştirilen X. Çalışma Meclisi'nde ele alınan konulardan biri de Kıdem Tazminatının İşçinin Bireysel Hesabına Yatırılması Hakkında Kanun Taslağı olmuştur. Özellikle kıdem tazminatının fondan ödenecek olması

10 Programın 235. maddesinde; "Sosyal taraflarla diyalog içerisinde tüm işçilerin faydalanacağı ve bireysel hesaba dayanan bir kıdem tazminatı sistemi geliştirilecektir" ifadesi yer almaktadır (Resmi gazete, 08.10.2013, Sayı: 28789 (Mükerrer). 
durumunda fona yatırılması gereken prim miktarı tartışılmış ve yapılan araştırmalar sonucunda fonun sürdürülebilirliği açısından $\% 5,6$ oranında prim kesintisi yapılması gerektiği vurgulanmıştır (ÇSGB, 2013: 74). Mevcut haliyle şu anki kıdem tazminatı bir işverene aylık \%8,3 oranında bir mali yük getirmektedir. 2002 yılında hazırlanan taslakta $\% 3$ olarak belirlenen ve yeterli görülmeyen bu oran, 2012 yılında hazırlanan taslakta ise \%4 olarak belirlenmiş ve bu orana ayrıca işverenlerin işsizlik sigortası prim payının \%1,5'inin ekleneceği belirtilmiştir. Dolayısıyla çalışma meclisinde belirtilen ve fonun sürdürülebilirliğinin sağlanması için gerekli prim oranı bu taslakta öngörülmüştür.

Kıdem tazminatı fon çalışmalarına 2016 yılında da devam edilmiştir. $\mathrm{Bu}$ yılda yapılan fon çalışmasında, mevcut çalışanların fona katılımları tercihlerine bırakılmış, işverenle anlaşmaları halinde fon sistemine geçebilecekleri ve işe yeni girenlerin ise fona katılımlarının zorunlu tutulduğu ifade edilmiştir. Bireysel emeklilik sisteminden esinlenerek yapılan fon çalışmasında, işverenin her çalışanın bireysel kıdem hesabına her ay prim yatırması ve ancak çalışanın kıdem hesabında biriken tazminatını erkenden çekme olanağının özel durumlar haricinde olmadığı belirtilmiştir. Aynı zamanda çalışanın, kıdem hesabında biriken tazminatını çeşitli yatırım fonlarında değerlendirme imkânına sahip olmakla birlikte istifa etmesi ve hizmet akdi işverence haklı ya da haksız bir şekilde feshedilmesi halinde de kıdem tazminatına hak kazanacağı bu çalışmada yer almıştır. Dolayısıyla bu fon çalışmasında işçi bir gün çalışmayla bile kıdem tazminatına hak kazanmış olacaktır (Nurdoğan vd., 2016: 1160).

4 Kasım 2019 tarihinde Resmi Gazete'de ${ }^{11}$ yayınlanan 2020 Y11 Cumhurbaşkanlığı Yıllık Programı içinde "bireysel emeklilikte otomatik katılımın tamamlayıcı emeklilik sistemine dönüştürülmesi” kararı yayınlandı. Bu kararla birlikte Tamamlayıcı Emeklilik Sistemi (TES) bağlamında kıdem tazminatında düzenlemeye gidilmesi öngörülmüştür. Aynı zamanda 11. Kalkınma Planı kapsamında yer alan politika ve tedbirler arasında, "bireysel emeklilikteki otomatik katılım sistemi, sistemde kalma süresini ve fon tutarını arttıracak biçimde yeniden düzenlenecek ve bireysel hesaplara dayalı kurulacak kıdem tazminatı fonu ile entegre edilecektir" hedefi yer almıştır (T.C. Cumhurbaşkanlığı, 2019: 34).

Emeklilik gelirlerinin ve tasarrufların arttırılması, kıdem tazminatında ortaya çıkan sorunların ortadan kaldırılması gerekçesiyle oluşturulması ve 2022 yılında

11 Resmi Gazete, Sayı: 30938 (Mükerrer), 04.11.2019 
uygulamaya konulması planlanan TES'de; zorunlu (karma) ve isteğe bağ lı olmak üzere iki model üzerinde çalışılmaktadır. Zorunlu olacak olan karma modele göre; her bir çalışma yılı için 30 günlük $(\% 8,33)$ ücret tutarında ödenen kıdem tazminatının 19 günlük $(\% 5,33)$ kısmı, mevcut sisteme göre işveren tarafından ödenecektir. Geri kalan 11 günlük (\%3) kısmı için ise çalışan adına bireysel fon oluşturulacak ve işveren fona ayl1k \%3 prim ödeyecektir. İsteğe bağlı olacak ikinci modelde ise; \%4 işveren katkısının yanı sıra \%1 devlet katkısı uygulanacaktır. Modelde çalışanların katkısı ise almış oldukları ücrete bağlı olarak değişiklik göstermektedir. Asgari ücretle çalışanların katkısı \%0,5, asgari ücretin iki katına kadar ücretle çalışanların katkısı \%1,5 ve asgari ücretin iki katından daha fazla ücretle çalışanların katkısı ise \%2,5 olarak öngörülmüştür. Ayrıca çalışanların tercihine bağlı olarak, yapacakları katkı payları aylık kazançlarının \%6'sına kadar artırılabilecektir (Anadolu Ajansı, 2020).

Bu sistemde çalışanlar, bir gün bile çalışmış olsa bireysel fon hesaplarındaki hakları saklı tutulacak ve istifa etmeleri halinde de bireysel fon hesaplarındaki tutarlar kazanılmış hak olarak kendilerine kalacaktır. Yapılacak düzenlemeyle kıdem tazminatı kapsamında kazanılmış haklarında korunması sağlanacaktır. Sisteme göre katılımc1 60 yaşını tamamladıktan sonra emekli olabilecek ancak 60 yaşın altındaki katılımcılara ilk kez konut edinmeleri, evlenmeleri, ağır hastalık geçirmeleri ve işsiz kalmalarından dolayı her biri için fondaki birikim tutarının \%10’u kadar ödeme yapılabilecektir. Ayrıca 60 yaşını dolduranlara talepte bulunmaları halinde emeklilik hesabındaki birikimlerinin \%25'ini geçmemek üzere defaten ödeme de yapılabilecektir (Anadolu Ajansı, 2020).

Günümüze kadar yapılan kıdem tazminatı fonu çalışmalarında, işçinin tazminata hak kazanabilmesi bazı özel durumlar hariç (evlilik, konut alımı, ağır hastalık, uzun süreli işsizlik vb.) emeklilik ya da belli bir süre (5-15 yıl arası) prim ödenmesi koşuluna bağlanmıştır. Dolayısıyla bu durum kıdem tazminatının niteliğini emeklilik ikramiyesine dönüştürme gayreti olarak kendini göstermektedir. Nitekim bu durumun ortaya çıkmasında diğer bir ifadeyle kıdem tazminatı yükünün işverenden alınıp fona devredilmesindeki en önemli gerekçe ise iş güvencesi ve işsizlik sigortası kanunlarının yürürlüğe girmiş olmasıdır (Limon, 2015: 165-166).

Yapılan fon çalışmalarında da görüldüğü üzere en tartışmalı konu ve işveren kesiminin ilk sırada yer alan talepleri kıdem tazminatı miktarının azaltılmasıdır. Daha önce de belirtildiği üzere 1975 yılında çıkarılan 1927 sayılı Kanun ile 
birlikte her geçen tam y1l için ödenecek kıdem tazminatı miktarı 15 günden 30 günlük ücret tutarına çıkarılmıştır. Dolayısıyla işveren kesimi 30 günlük ücret üzerinden hesaplanan kıdem tazminatı yükünün azami 15 günlük ücret tutarına indirilmesini istemektedir. Mevcut haliyle şu anki kıdem tazminatı bir işverene aylık \%8,3 oranında bir mali yük getirmektedir. Ancak bilimsel çalışmalarda, yapılan aktüeryal hesaplamalar ve fondaki birikimin finansal yatırım araçlarıyla değerlendirilmesiyle prim oranının fonun sürdürebilirliği açısından en az $\% 5$ ile \%6 aralığında olması gerektiği sonucuna varılmıştır (Aygören vd., 2012: 132). Bu da işverenlerin ilk sırada yer alan taleplerine paralel olarak kıdem tazminatı miktarının yaklaşık 20 günlük ücret tutarına kadar indirilebileceğini göstermektedir.

Bugüne kadar yapılan fon çalışmalarında asıl amaç, çalışanların kıdem tazminatı almalarında sorun yaşamaması ve kıdem tazminatı hakkını garanti edecek bir sistemin oluşturulmasıdır. Özellikle bu doğrultuda oluşturulacak fon sistemiyle birlikte işçiler, işyerlerindeki çalışmalarının karşılığını istifa etseler ve bir gün bile çalışmış olsalar da almaya hak kazanacaklardır. Böylelikle hem işçiler kıdemi yanacak diye işinden istifa edememe sorunu ortadan kalkacak hem de işverenler yüklü kıdem tazminatı ödemeleriyle karşı karşıya kalmayacaklardır. Ayrıca fon sisteminin oluşturulmasıyla birlikte iş mahkemelerinde büyük bir yoğunluk oluşturan kıdem tazminatı davaları da büyük oranlarda azalmış olacaktır.

\section{İşsizlik Sigortası}

İşsizlik sigortası adından da anlaşılacağı üzere işsizlikle bağlantılı bir sigorta koludur. "Bir ülkede artmakta olan işgücü arzının, yeterli bir şekilde gelişim gösteremeyen üretim sahalarına sığdırılamamasından kaynaklanan işsizlik”, hem birey hem de toplum açısından önemli bir risk unsurudur (Zaim, 1997: 170). Dolayısıyla, gelişmiş ve gelişmekte olan ülkelerde sosyo-ekonomik nitelikli bir risk türü olan işsizliğe karşı sosyal güvenliğin temini, ciddi bir gereksinim olarak önem arz etmektedir.

Sanayinin hızla gelişmesine karşın, Batı'da 19. yüzyılın ilk dönemlerinde, çalışanlara yönelik sosyo-ekonomik ve fizyolojik riskleri karşı sosyal güvenlik uygulamalarından söz edilmemektedir. Sosyo-ekonomik risk olan işsizlik sigortası, ihtiyarlık, ölüm gibi sigorta kolu olan fizyolojik risklerden daha geç gelişen bir sigorta koludur. İhtiyarlık, ölüm gibi sigorta kolları 19.yüzyılın 
sonlarına doğru uygulamaya konulmasına karşın, işsizlik sigortası 20.yüzyılın ilk çeyreğinde uygulamaya konulmuştur. İşsizlik riskini önlemeye yönelik ilk tedbirler, sendikal faaliyetlerin gelişmeye başladığı sanayi ülkelerinde lonca sistemi içerisindeki yardımlaşma sandıkları ile sendikalar aracılığıyla alınmaya çalışılmıştır. Osmanlı Devleti’nde benzer bir sistemi ise ahilik teşkilatı içerisindeki "esnaf sandığı" adı altında yardım sandıkları ile görmek mümkündür (Taşçı ve Yılmaz, 2009: 606).

Özellikle bu dönemde yoğunlaşan işsizlik karşısında sendikalar, işçilerin uğradığı kayıpların giderilmesi ve az da olsa gelir güvencesinin sağlanması yönünde isteğe bağlı işsizlik sigortası fonları oluşturmuşlardır (Başterzi, 1996: 60). Bu kapsamda ilk sendikal yapı, 1832 yılında İngiltere' de çelik dökümcüleri sendikası tarafından, ilk işsizlik sigortası fonu da 1892 yılında İsveç’te matbaacılar sendikası tarafından kurulmuştur (Holmlund, 1998: 113). Yine bu dönemde çok yaygın olarak görülmese de işverenlerin işyerlerinde çalışma istikrarını arttırmak, işçi devrini azaltmak, işçilerin sadakatini arttırmak gibi nedenlerle isteğe bağlı işsizlik sigortası fonları kurdukları görülmüştür. 1890'lı yıllardan itibaren belediyeler de ister sendikalı ister sendikasız olsun bütün işçileri kapsayan isteğe bağlı işsizlik sigortası fonları oluşturmaya başlamışlardır. Sistemin ilk örneğine 1893 'te İsviçre'nin Bern şehrinde rastlanmış ve daha sonra bu uygulama 1896'da Almanya'nın Köln ve 1905'de de Leipzig şehirlerine yayılmıştır (Yazgan, 1969: 153).

Diğer yandan Belçika'da 1901 yılında "Ghent" adı verilen ve sendikalarla belediyelerin işbirliğine dayalı isteğe bağlı işsizlik sigortası fonu şeklinde bir sistem ortaya çıkmıştır. Takip eden yıllarda bu sistemin Belçika'nın bütününe yayıldığı ve Avrupa' da birçok ülkede de uygulandığı görülmüştür (Vandaele, 2006: 648-649). Ancak, Ghent sistemi işsizliğe eğilimli kimselere cazip gelmiş, bunların sistemi kötüye kullanmaları ve belediyelerin fonlara işçilerin katılımlarından daha fazla yardım yapar duruma gelmesi nedeniyle başarısız olmuş ve sistemden vazgeçilmiştir (Başterzi, 1996: 61). Yasal temele dayalı ilk zorunlu işsizlik sigortasını uygulamaya koyan ülke, 1911 yılında Lloyd George'un Başbakanlığı dönemindeki İngiltere'dir. Bu ülkeyi daha sonra sırasiyla 1911'de İrlanda, 1919'da İtalya ve İspanya, 1920'de Avusturya ve Belçika, 1927'de Almanya ve 1945 'te de Yunanistan izlemiştir. Türkiye'de ise işsizlik sigortası 1999 'da kabul edilen yasa ile uygulamaya konulmuştur (Tuncay ve Ekmekçi, 2011: 470-471). 
İşsizlik sigortası; çalışma isteğine, yeteneğine ve gücüne sahip olmasına karşın, işini kendi iradesi ve kusuru dışında kaybeden çalışanların maruz kaldıkları gelir kaybını kısmen ve geçici bir süre için telafi eden ve prim sistemine dayanan bir sigorta koludur. ILO’nun tanımına göre işsizlik sigortası; "isteği dışında işi sona eren bağımlı çalışanların gelir kaybını kısmen ve geçici bir süre telafi eden bir sigorta koludur" (Korkmaz ve Mahiroğulları, 2007: 87). Bu tanımlardan da anlaşılacağı üzere işsizlik sigortası, işsizlerin karşı karşıya kaldıkları gelir kaybını telafi etmeye çalışan, sigortacılık tekniği ile faaliyette bulunan ve sosyal güvenlik sistemi içerisinde yer alan bir sigorta koludur. İşsizlik sigortası işsizlere maddi olanakların yanı sıra mesleki eğitim ve işe yerleştirme hizmeti de sunmaktadır. Bu uygulama kayıtdışı istihdamın kayıt altına alınmasına da katkı sağlamaktadır. Ayrıca, işçilerin işsizlik ödeneğine hak kazanabilmesi için ahlak ve iyi niyet kurallarına uyulması konusunda daha duyarlı olunacağından, uygulamanın verimliliği arttırdığı da söylenebilir (Biçerli, 2011: 492).

İlerleyen zamanlarda meydana gelme olasılığı olan işsizlik riskine karşı çalışanlara güvence sağlamak işsizlik sigortasının temel amacını oluşturmaktadır. Böylelikle gelecekte işini kaybetme ihtimali bulunan işçiler, çalıştıkları dönemlerde düzenli bir şekilde prim ödemeleri şartıyla işsiz kalınması durumunda gelir kaybını telafi edecek bir gelire sahip olabileceklerdir. İsteği dışında işini kaybeden bir kişinin moral yapısı, ailesi ve topluma özgü yol açabileceği sıkıntılara karşı korunmasının sağlayacağ faydalar önem teşkil etmektedir (Törüner, 1992: 4). İşsizlik sigortasının toplumsal açıdan ise iki temel amacı vardır. Birincisi işsizliğin kişiler üzerindeki olumsuz etkilerini en az düzeye indirgeyerek toplumsal dengeyi bozmaya yönelik sonuçları ve suç eğilimini önlemektir. İkinci amacı ise çalışanın işsiz kaldığı süre zarfında satın alma gücünün korunmasıyla birlikte üretimin giderek azalmasının ve işsizlik artışının önüne geçilmesidir (Biçerli, 2011: 492-493).

Türkiye'nin de 1971 yılında onayladığg ILO’nun 28 Haziran 1952 tarihli 102 sayılı "Sosyal Güvenliğin Asgari Normları" sözleşmesinde sosyal güvenliğin asgari normları belirtilmiş ve işsizlik riskine IV. ve IX. bölümlerde yer verilmiştir. IV. bölümün 20. maddesinde, işsizlik sigortasından yararlanma hali; "çalışma gücünde olan ve iş aramaya hazır bulunan bir kimsenin, uygun bir iş bulma imkânsızlığı nedeniyle ve ulusal mevzuatta açıklanan şekilde, kazancın geçici olarak durması halidir” şeklinde belirtilmiştir. Yine sözleşmenin 
67. maddesinde işsiz kalan işçiye ödenecek işsizlik sigortası miktarı belirtilmiş olup, evli ve iki çocuklu erkek işsizin son ayda almış olduğu ücretin \%45'inin altında bir tutar olmaması öngörülmüştür (ÇSGB, 1998: 254-273). İşsizlik sigortası finansmanında genel olarak üç farklı yöntem kullanılmaktadır. Bunlar, tüm bedelin işveren ya da devlet tarafından tek taraflı ödendiği tekli finansman yöntemi, bedelin işçi ve işveren tarafından birlikte ödendiği ikili finansman yöntemi, bedelin işçi, işveren ve devlet tarafından birlikte ödendiği ve dünyada yaygın olarak kullanılan üçlü finansman yöntemidir (Gençler, 2002: 16).

İşsizlik sigortası, işini kaybedenlerin emek piyasasından ve çalışma disiplininden uzaklaşmamasını sağlamaya yönelik hizmetler sunarken, bazı durumlarda ise tam tersi olarak işsizlik artışına da yol açabilmektedir. Nitekim işsiz kalan bireyler gelir getirici bir işte çalışmanın yerine işsizlik ödeneğinden yararlanmayı düşünebilmektedir. Özellikle işsizlik ödeneğinin uzun süreli ve yüksek düzeyden ödendiği durumlarda bu sorunla sıklıkla karşılaşılabilmektedir. 20 OECD ülkesinde yapılan bir araştırmada, işsizlik ödeneğinin tutarı \%10 arttırıldığında veya işsizlik ödeneğinin süresi bir ay uzatıldığında, \%1 oranında işsizlik artışı yaşandığı sonucu ortaya çıkmıştır. ABD' de yapılan bir çalışmada ise işsizlik ödeneği tutarındaki \%10'luk bir artış, işsizlik süresinin bir hafta daha uzamasına neden olduğu sonucuna varılmıştır (Varçın, 2004: 17).

Yine yapılan çalışmalarda işsizlik sigortası ödemelerinin yüksek olduğu bazı ülkelerde bu ödemelerin rezervasyon ücretlerini arttırdığı ortaya çıkmıştır. Rezervasyon ücretlerinin artış göstermesi işsizlerin, kendilerine teklif edilen işlerin kabul edilmesi sırasında daha seçici olmalarına ve bu durum da işsizlik sürelerinin uzamasına neden olmaktadır (Siebert, 1997: 15-18). Ancak çoğu ülkede uygulamanın bu sakıncasını gidermek amacıyla işsizlere önerilen uygun bir işin kabul edilmesi zorunluluğu getirilmiş ya da sınırlı sayıda iş önerisi reddetme hakkı verilmiştir. İşin kabul edilmemesi veya belirlenen sayının aşılması durumunda işsizlik ödeneği kesilmekte, askıya alınmakta ya da ödeme miktarı önemli ölçüde azaltılmaktadır. Bu uygulamanın işsizlik sigortasının iş kabul ücretlerini arttırmaktan çok azalmasına yönelik bir baskı oluşturduğu söylenebilir (Kapar, 2005: 110-111).

\section{Türkiye'de İşsizlik Sigortasının Tarihsel Gelişimi}

Türkiye' de işsizlik sigortasının kurulmasına yönelik ilk ciddi çalışma ILO uzmanlarından Philip Booth'un 1959 yılında hazırlamış olduğu rapor 
kapsamında İş ve İşçi Bulma Kurumu (İİK) ile Devlet Planlama Teşkilatı (DPT) öncülüğünde başlamış ve 4447 sayılı İşsizlik Sigortası Kanunu'nun yürürlüğe girmesine kadar yaklaşık 30 yasa tasarısı ve teklifi hazırlanmıştır. Ayrıca 1992 yılında düzenlenen işsizlik sigortası temalı VIII. Çalışma Meclisi de Türkiye'de işsizlik sigortasının gelişimine ve oluşumuna önemli katkılar sağlamıştır. İşsizlik sigortası, 1985-1989 yılları arasını kapsayan V. Kalkınma Planı hariç tüm kalkınma planlarında yer almasına rağmen ancak 1996-2000 yılları arasını kapsayan VII. Beş Yıllık Kalkınma Planı döneminde 25 Ağustos 1999 tarihinde kabul edilen 4447 Sayılı İşsizlik Sigortası Kanunu ile yürürlüğe girmiştir. Bu tarihe kadar Türkiye işsizlik sigortası programı olmayan tek OECD ülkesi olmuştur. Kanunun kabul edilmesiyle birlikte prim tahsilatına 01 Haziran 2000 tarihinde ve ilk işsizlik ödenekleri ise 2002 yılı Mart ayında verilmeye başlanmıştır (Şen, 2019: 173).

İşsizlik sigortasının yasal bir çerçeveye kavuşmasındaki gecikmelerin nedenleri çeşitli yönlerden değerlendirilmektedir. İşçi ve işverenler için mevcut yüksek SSK primlerinin üstüne işsizlik sigortası primlerinin de eklenmesi ile yükün daha da artacağı endişesi bu nedenlerden bir tanesidir. Buna ek olarak işsizliğe ilişkin bilgilerin ve özellikle istatistiklerin yetersiz ve eksik olması işsizlik sigortasının uygulamasını olumsuz yönde etkileyeceği düşüncesi de önemli nedenler arasında yer almaktadır. İşsizlik oranının yüksek olması, işsizlerin çoğunluğunun niteliksiz olması ve yapısal işsizliğin devam etmesi de diğer nedenler olarak söylenebilir. Ayrıca tasarruf fonlarının yetersiz olması, finansman zorluklarının ve kronikleşmiş bütçe açıklarının bulunması, uygulamanın aktüeryal ve yönetimsel açıdan güç ve karmaşık olması gibi nedenler de, işsizlik sigortasının geç tarihlerde yürürlüğe girmesi kapsamında değerlendirilmektedir (Tuncay ve Ekmekçi, 2011: 468).

Ancak Türkiye'de işsizlik sigortasının geç tarihlerde uygulamaya konulmasının en önemli nedeni kıdem tazminatının 1936 yılından itibaren uygulamada olmasıdır. İşsizlik sigortası çalışmaları kıdem tazminatının varlığı nedeniyle sürekli ertelenmiş, işverenlere kıdem tazminatının yanında ağır bir yük oluşturacağı ve özellikle kıdem tazminatının bir niteliğinin de işsizlik tazminatı olduğu düşüncesiyle işveren kesiminden eleştiriler almıştır. Ayrıca sosyal güvenlik risklerini 9 başlık altında inceleyen ve bunlardan bir tanesi de işsizlik sigortası olan ILO’nun 102 Sayılı “Sosyal Güvenliğin Asgari Normları Sözleşmesi” 1971 yılında Türkiye tarafından onaylanmasına rağmen işsizlik 
sigortası kısmına kıdem tazminatı uygulaması gerekçe gösterilerek çekince konulmuştur. Hâlbuki ILO tarafindan 1982 yılında kabul edilen ve 1994 yılında da Türkiye tarafından onaylanan 158 Sayılı "Hizmet İlişkisine Son Verilmesi Sözleşmesi”, kıdem tazminatı ve işsizlik sigortası uygulamalarının birlikte var olabileceğini öngörmektedir (Ünsal, 2008: 33).

\section{İşsizlik Sigortasından Yararlanma Koşulları ve İşsizlik Ödeneği Miktarı}

4447 sayılı Kanunun 46.maddesinin 2.fikrasına göre işsizlik sigortas1; "5510 sayılı Sosyal Sigortalar ve Genel Sağlık Sigortası Kanunu’nun 4.maddesinin 1.fikrasının (a) bendi ile 2.fikrası kapsamında olanlardan bir iş sözleşmesine bağlı olarak çalışan sigortalıları, 4857 sayılı Kanuna göre kısmi süreli iş sözleşmesi ile çalışanlardan 5510 sayılı Kanunun 52.maddesinin 1.fikrası kapsamında işsizlik sigortası primi ödeyen isteğe bağlı sigortalılar ile aynı Kanunun ek 6. maddesi kapsamındaki sigortalıları ve 506 sayılı Sosyal Sigortalar Kanununun geçici 20.maddesinde açıklanan sandıklara tabi sigortalıları" kapsamaktadır.

İşsizlik sigortasının finansmanı üçlü finansman yöntemine göre sağlanmaktadır. İşçinin SSK primine esas kazancı üzerinden $\% 2$ işçi ve $\% 3$ işverenden kesilirken ve buna $\% 2$ oranında da Devlet katkıda bulunurken, bu oranlar ücret dışı işletme yüklerinin hafifletilmesi kapsamında 2001 y1lında birer puan indirilerek \%1 işçi, \%2 işveren ve \%1 Devlet şeklinde değiştirilmiştir. İşsizlik sigortasından yararlanabilmek için; kendi iradesi ve kusuru dışında işsiz kalmak (iş sözleşmesinin 4857 sayılı İş Kanunu’nun “ahlak ve iyi niyet kurallarına uymayan haller ve benzerleri” başlıklı 25.maddenin 2.bendinde sayılan hususlarla ve kendi isteğiyle sona ermemesi), iş sözleşmesinin feshinden önceki son 120 gün içinde prim ödeyerek sürekli çalışmış olmak, son 3 yıl içerisinde en az 600 gün süre ile işsizlik sigortası primi ödemiş olmak ve iş sözleşmesinin feshinden itibaren 30 gün içerisinde en yakın İŞKUR birimine şahsen ya da elektronik ortamda başvurmak gerekmektedir (Kutal, 2002: 172-175).

İşsizlik Sigortası Kanunun 49.maddesine göre; "işsizlik sigortası primlerinin toplanmasından, sigortalı ve işyeri bazında kayıtların tutulmasından, toplanan primler ile uygulanacak gecikme cezası ile gecikme zammının işsizlik sigortası fonuna aktarılmasından, teminat ve hak edişlerin prim borcuna karşıllı tutulmasından, yersiz olarak alınan primlerin iadesinden Sosyal Güvenlik Kurumu görevli ve yetkili” kılınmıştır. Aynı kanunun 50.maddesine göre; 
"hizmet akdinin feshinden önceki son 3 y1l içinde; 600 gün sigortalı olarak çalışıp işsizlik sigortası primi ödemiş olan sigortalı işsizlere 180 gün (6 ay), 900 gün sigortalı olarak çalışıp işsizlik sigortası primi ödemiş olan sigortalı işsizlere 240 gün ( 8 ay) ve 1080 gün sigortalı olarak çalışıp işsizlik sigortası primi ödemiş olan sigortalı işsizlere 300 gün (10 ay) süre ile işsizlik ödeneği verilmektedir". İşsizlik ödeneğine hak kazananlara İŞKUR tarafından ödeneğin yanı sıra, genel sağlık sigortası primleri ödenmesi, yeni bir iş bulma ve meslek geliştirme, edindirme ve yetiştirme eğitimi hizmetleri de sağlanmaktadır.

Yine Kanunun 50.maddesine göre günlük işsizlik ödeneği, 2002 yılından 2008 yılı Temmuz ayına kadar sigortalının son 4 aylık prime esas kazançları dikkate alınarak hesaplanan günlük ortalama net kazancın \%50'si olarak hesap edilmiştir. Yapılan değişikliklerle birlikte 2008 yılı Temmuz ayından itibaren günlük işsizlik ödeneği; sigortalının son 4 aylık prime esas kazançları dikkate alınarak hesaplanan günlük ortalama brüt kazancın $\% 40{ }^{\prime} 1^{12}$ olarak hesaplanmaktadır. Hesaplanan işsizlik ödeneği miktarı ise, aylık asgari ücretin brüt tutarının \%80'ini geçememektedir. İşsizlik ödeneği damga vergisi hariç herhangi bir vergi ve kesintiye tabi tutulmamış, nafaka borçları haricinde haciz edilmesi ve başkalarına devredilmesi de mümkün kılınmamıştır.

İşsizlik ödeneğinin bazı durumlarda kesildiği kanunun 52. maddesinde belirtilmiştir. Bunlar; mesleğine, ikametine ve bir önceki işin koşullarına uygun olarak İŞKUR tarafından teklif edilen işlerin geçerli bir sebebe dayalı olmaksızın reddedilmesi, işsizlik ödeneğinin alındığı dönemlerde kayıt dışı olarak çalışılması, işsizlik ödeneği aldığı süre içerisinde yaşlılık aylığı almaya başlamak ve İŞKUR tarafindan önerilen mesleki eğitim kurslarına katılmayı reddetmek, devam etmemek, kurum tarafindan yapılan çağrıları cevaplamamak, istenilen bilgi ve belgeleri vermemektir.

12 Asgari ücretle çalışan bir işçinin alacağı işsizlik ödeneği; binde 7,59 damga vergisi kesintisinden sonra 1420,14 TL'dir. Ayrıca işsizlik ödeneği, brüt asgari ücret tutarının \%80'i olan 2862 TL'yi (damga vergisi kesintisi hariç) geçemez. 
Tablo 1

İssizlik Sigortası Ödeneği Verileri (2002-2020)

\begin{tabular}{|l|c|c|c|c|}
\hline Yıllar & Başvuru & Hak Eden & Hak Edemeyen & $\begin{array}{c}\text { Ödeme Miktarı } \\
\text { (Bin TL) }\end{array}$ \\
\hline $\mathbf{2 0 0 2}$ & 96.364 & 83.603 & 12.761 & 46.814 \\
\hline $\mathbf{2 0 0 3}$ & 143.155 & 118.437 & 24.718 & 125.978 \\
\hline $\mathbf{2 0 0 4}$ & 169.409 & 127.528 & 41.881 & 199.890 \\
\hline $\mathbf{2 0 0 5}$ & 208.051 & 186.231 & 21.820 & 270.072 \\
\hline $\mathbf{2 0 0 6}$ & 220.694 & 199.441 & 21.253 & 316.989 \\
\hline $\mathbf{2 0 0 7}$ & 246.596 & 221.498 & 25.098 & 351.907 \\
\hline $\mathbf{2 0 0 8}$ & 382.132 & 331.413 & 50.719 & 517.054 \\
\hline $\mathbf{2 0 0 9}$ & 597.230 & 473.211 & 124.019 & 1.114 .275 \\
\hline $\mathbf{2 0 1 0}$ & 459.470 & 331.796 & 127.674 & 807.412 \\
\hline $\mathbf{2 0 1 1}$ & 499.244 & 323.072 & 176.172 & 791.051 \\
\hline $\mathbf{2 0 1 2}$ & 609.548 & 372.294 & 237.254 & 966.185 \\
\hline $\mathbf{2 0 1 3}$ & 733.093 & 432.369 & 300.724 & 1.272 .486 \\
\hline $\mathbf{2 0 1 4}$ & 901.952 & 515.088 & 386.864 & 1.657 .723 \\
\hline $\mathbf{2 0 1 5}$ & 1.086 .979 & 594.391 & 492.588 & 2.192 .787 \\
\hline $\mathbf{2 0 1 6}$ & 1.521 .514 & 805.677 & 715.837 & 3.682 .651 \\
\hline $\mathbf{2 0 1 7}$ & 1.329 .403 & 701.232 & 628.171 & 4.169 .246 \\
\hline $\mathbf{2 0 1 8}$ & 1.636 .260 & 845.513 & 790.747 & 4.824 .136 \\
\hline $\mathbf{2 0 1 9}$ & 1.955 .041 & 1.013 .056 & 941.985 & 7.985 .061 \\
\hline $\mathbf{2 0 2 0}$ & 1.496 .461 & 539.540 & 956.921 & 6.201 .456 \\
\hline Toplam & $\mathbf{1 4 . 2 9 2 . 5 9 6}$ & $\mathbf{8 . 2 1 5 . 3 9 0}$ & $\mathbf{6 . 0 7 7 . 2 0 6}$ & $\mathbf{3 7 . 4 9 3 . 1 7 3}$ \\
\hline
\end{tabular}

Kaynak: https://www.iskur.gov.tr/kurumsal-bilgi/yayinlar/

Tablo 1'de 2002 ile 2020 yılları arasında işsizlik sigortası ödeneği başvuran, hak eden ve edemeyen kişi sayıları ile ödeme miktarları yer almaktadır. 2002 yılından 2020 yılına doğru hem başvuru sayılarında hem de hak eden sayıları ile ödeme miktarında gözle görülür bir artış yaşandığı görülmektedir. Ancak işsizlik sigortası ödeneğine hak kazanamayanların sayısı da yıllar itibariyle artış göstermiştir. Tabloda da görüldüğü üzere bugüne kadar işsizlik ödeneği almak için başvuranlardan sadece \%57'si ödeneğe hak kazanırken \%43'ü ise hak kazanamamıştır. Dolayısıyla bu durum işsizlik sigortasının amacını gerçekleştirmede yetersiz kaldığını ve yararlanma koşullarının gözden geçirilmesi gerektiğini göstermektedir. Aynı zamanda tabloda 2002 yılından 2020 yılına kadar yapılan toplam işsizlik ödeneği miktarının da yaklaşık 37,5 milyar TL olduğu görülmektedir.

2015 yılında gerçekleştirilen XI. Çalışma Meclisi'nde işsizlik sigortasına yöneltilen eleştirilerin çoğunluğunu, işsizlik sigortasının özellikle yararlanma 
koşullarının çok katı olduğu ve koşulların esnetilmesi oluşturmuştur (ÇSGBb, 2013: 28). Bu doğrultuda hizmet akdinin feshinden önceki son 120 gün kesintisiz olarak prim ödeme şartının indirilmesi ya da kaldırılması ve son üç yıl içerisinde 600 gün ${ }^{13}$ işsizlik sigortası prim ödeme şartının indirilmesi, işsizlik ödeneğine hak kazananların sayısını mutlak olarak arttıracaktır. Nitekim 2014-2018 yılları arasını kapsayan X. Kalkınma Planı'nda; “işsizlik sigortasından yararlanma şartlarının esnetilmesi ve yararlanma sürelerinin arttırılması” ve UİS'in 20172019 eylem planları içerisinde de "işsizlik sigortasının daha fazla sosyal koruma sağlayacak biçimde yeniden düzenlenmesi" "14 hedefi yer almasına rağmen henüz bu hedefler gerçekleştirilememiştir (T.C. Cumhurbaşkanlığı, 2013: 165). Ayrıca planda da belirtildiği üzere işsizlik ödeneği miktarının, sürelerinin ve tavan miktarının arttırılması da işsizlik sigortası uygulamasının daha etkin bir şekilde sürdürülmesini sağlayacaktır.

\section{İşsizlik Sigortası Fonu ve Fonun Görünümü}

4447 sayılı İşsizlik Sigortası Kanunu'nun gerektirdiği görev ve hizmetler için malî kaynak sağlamak, piyasa şartlarında kaynakları değerlendirmek, Kanunun öngördüğü ödemelerde bulunmak üzere "İşsizlik Sigortası Fonu" kurulmuştur. Kanun'un 53.maddesinde de belirtildiği üzere Fon, Kurum Yönetim Kurulunun kararları çerçevesinde ve Kurumun "Fon Yönetimi ve Aktüerya Dairesi Başkanlığı” vasıtasıyla işletilir ve yönetilir. Dolayısıyla İşsizlik Sigortası Fonu, Türkiye İş Kurumu Yönetim Kurulu kararları ile yönetilen, işsizlik sigortası primleri ile diğer gelirlerinin ve devlet katkılarının toplandığı devlet güvencesinde bir fondur.

İssizlik Sigortası Kanunu'nun 53.maddesinde fonun gelir ve giderleri belirtilmiş̧tir. Gelirler; işsizlik sigortası primlerinden, bu primlerin değerlendirilmesinden elde edilen kazanç ve iratlardan, fonun açık vermesi durumunda devlet tarafından sağlanacak katkılardan, bu Kanun gereğince sigortalı ve işverenlerden alınacak ceza, gecikme zammı ve faizlerden, diğer gelir ve kazançlar ile bağışlardan oluşmaktadır. Giderler ise sadece işini

13 Kısa çalışma ödeneğinden yararlanabilmek için Covid-19 nedeniyle 120 günlük süre 60 güne ve 600 günlük süre ise 450 güne indirilmiş̧ir. Dolayısıyla pandemi sonrasında da bu sürelerin sadece kısa çalışma ödeneğine hak kazanmada değil işsizlik ödeneğine de hak kazanmada bu şekilde ya da daha da indirilerek devam etmesi, işsizlik ödeneğinden daha fazla işsizin yararlanmasını sağlayacaktır.

$14 \mathrm{Bu}$ hedef kapsamında yer alan tedbir, "işsizlik sigortası fonunun aktüeryal dengesi gözetilerek işsizlik sigortası hak kazanma şartları, ödeme süresi ve ödeme miktarı özel politika gerektiren grupları da dikkate alarak iş aramayı teşvik edici şekilde iyileştirilecektir" şeklinde belirtilmiştir. 
kaybeden işsizlere yapılan ödenekten oluşmamaktadır. İşsizlik ödeneğine ek olarak farklı yıllarda fonun kullanımına yönelik yapılan yasal düzenlemelerle birlikte giderler artış göstermiştir. Özellikle bu yönde ağır eleştiriler alan ve işsiz kalanlara gelir güvencesinin sağlanmasının yanında tüm işsizlere yönelik farklı gider kalemlerinin oluşturulması işsizlik sigortasının ve fonunun amacından uzaklaştığını göstermektedir.

Nitekim 26 Mayıs 2008 tarihli 5763 Sayılı İş Kanunu ve Bazı Kanunlarda Değişiklik Yapılması Hakkında Kanun ile birlikte işsizlik sigortasının amacını belirten 4447 Sayılı Kanunun 46.maddesi değiştirilmiştir. Yapılan değişiklikle birlikte ilgili maddeden "sigortalı işsizlere işsiz kalmaları halinde" ifadesi çıkartılarak madde "işsizlik sigortasına ilişkin kuralları ve uygulama esaslarını düzenlemek ve bu Kanunda öngörülen hizmetlerin verilmesini sağlamak” şeklinde yeniden düzenlenmiştir. Bu değişikle birlikte fondan yapılan yardımlardan sadece işsizlik sigortasının hedef aldığ 1 sigortalı işsizler değil tüm işsizler yararlanmaya başlamıştır. Daha sonra Kanunun 48/7.maddesindeki değişiklik ${ }^{15}$ ile Fondan karşılanmak üzere sigortalı işsizler ile birlikte Kuruma kayıtlı tüm işsizlere iş bulma, danışmanlık ve mesleki eğitim faaliyetleri de verilmeye başlanmıştır (Arıcı, 2010: 178).

Fonun giderleri başlangıçta, sigortalı işsizlere verilen ödeneklerden, 5510 sayılı Kanun gereği ödenecek genel sağlık sigorta primlerinden, meslek geliştirme, edindirme ve yetiştirme eğitimi giderlerinden, işsizlik sigortası hizmetlerinin yerine getirilebilmesi için Yönetim Kurulunun onayı üzerine Kurum tarafindan yapılan giderlerden, ücret garanti fonu ödemelerinden, kisa çalışma ödeneklerinden oluşmuştur. Daha sonra ise bu giderlere; 18 yaşından büyük ve 29 yaşından küçük olanlar ile yaş şartı aranmaksızın 18 yaşından büyük kadınlar için prime esas kazanç alt sınırı üzerinden hesaplanan sigorta primine ait işveren hisseleri ${ }^{16}$, işsizlik ödeneği alanların işe alındığ 1 tarihten önceki aydan başlayarak işe alan işyerine ait prime esas kazanç alt sınırı üzerinden hesaplanan işçi ve işveren payı sigorta primleri ile genel sağlık sigortası primi ${ }^{17}$, ilave istihdam olarak işe alınanların prime esas kazanç alt

155763 Sayılı Kanunun 14.maddesi ve 13 Şubat 2011 tarihli 6111 Sayılı "Bazı Alacakların Yeniden Yapılandırılması İle Sosyal Sigortalar Ve Genel Sağlık Sigortası Kanunu Ve Diğer Bazı Kanun Ve Kanun Hükmünde Kararnamelerde Değişiklik Yapılması Hakkında Kanun"un 69.maddesi ile yapılan değişiklikler.

165763 Sayılı Kanunun 20.maddesi ile 4447 sayılı Kanuna eklenen Geçici 7.madde

1711 Ağustos 2009 tarihli 5921 Sayılı "İşsizlik Sigortası Kanunu İle Sosyal Sigortalar Ve Genel Sağlık Sigortası Kanununda Değişiklik Yapılmasına Dair Kanun”un 1.maddesiyle 4447 Sayılı Kanunun 50.maddesinin 5.fikrası yeniden düzenlenmiştir. 
sınırı üzerinden hesaplanan işveren sigorta primi giderleri ${ }^{18}$, Eynez, Atabacası, Işıklar ve Ermenek ilçelerindeki maden ocaklarında hak sahiplerine yapılan ödemeler ${ }^{19}$, Güneydoğu Anadolu Projesi (GAP) kapsamındaki yatırımlar için bütçeye aktıran miktarlar ${ }^{20}$, doğum ve evlat edinme sonrası yarım çalışma ödeneği ödemeleri ve prim giderleri ${ }^{21}$, nakdi ücret desteği kapsamında yapılan ödemeler ${ }^{22}$, işbaşı eğitim programı giderleri ${ }^{23}$, fonun menkul kıymet gelirlerinden stopaj vergi kesintisi ${ }^{24}$ eklenmiştir ${ }^{25}$.

İlk başlarda işsizlik sigortası hizmetlerinin yerine getirilmesi amacıyla kurulmuş ve giderleri bu hizmetlerle sınırlanmış olan İşsizlik Sigortası Fonuna her geçen y1l önemli gider kalemleri eklenmiştir. İşsizlik sigortası primlerinin 2000 yılından itibaren kesilerek Fonda birikmeye başlamasına karşın işsizlik ödeneklerinin 2002 yılında verilmeye başlanması, sigortalı işsizlere verilecek olan işsizlik ödeneğinin miktarı ve yararlanma süresinin düşük tutulması, Fon kaynaklarının sadece işini kaybedenlere yönelik kullanılması Fondaki birikiminin önemli miktarlara ulaşmasına olanak sağlamıştır. Ancak İşsizlik Sigortası Fonundaki birikimin giderek büyümesi, Fondaki gider kalemlerinin artışına neden olacak düzenlemeleri de beraberinde getirmiştir (Tozan, 2013: 111).

2008 yılında İşsizlik Sigortası Kanunu 46.maddede yapılan değişiklikle birlikte Fondaki mevcut giderlere ek olarak GAP kapsamındaki yatırımlar

185921 Sayılı Kanunun 2.maddesi ile 4447 Sayılı Kanuna eklenen Geçici 9.madde ve 6111 Sayılı Kanunun 74.maddesiyle 4447 Sayılı Kanuna eklenen Geçici 10.madde

1918 Haziran 2014 tarihli 6545 Sayılı "Türk Ceza Kanunu İle Bazı Kanunlarda Değiş̧iklik Yapılmasına Dair Kanun"un 102.maddesiyle 4447 Sayılı Kanuna eklenen Geçici 12.madde ve 4 Nisan 2015 tarihli 6645 Sayılı "İş Sağlığı Ve Güvenliği Kanunu İle Bazı Kanun Ve Kanun Hükmünde Kararnamelerde Değişiklik Yapılmasına Dair Kanun"un 26.maddesiyle 4447 Sayılı Kanuna eklenen Geçici 13.madde

205763 Sayılı Kanunun 19.maddesi ile 4447 sayılı Kanuna eklenen Geçici 6.madde

2129 Ocak 2016 tarihli 6663 Sayılı "Gelir Vergisi Kanunu İle Bazı Kanunlarda Değişiklik Yapılmasına Dair Kanun"un 20.maddesiyle 4447 Say1lı Kanunda düzenlenen Ek 5.madde

2216 Nisan 2020 tarihli 7244 Sayılı "Yeni Koronavirüs (Covid-19) Salgınının Ekonomik Ve Sosyal Hayata Etkilerinin Azaltılması Hakkında Kanun İle Bazı Kanunlarda Değişiklik Yapılmasına Dair Kanun"un 7.maddesiyle 4447 Sayılı Kanuna eklenen Geçici 24.madde

236663 Sayılı Kanunun 19.maddesiyle 4447 Sayılı Kanunun 53.maddesine eklenmiş̧tir.

2431 Mayıs 2012 tarihli 6322 Sayılı” Amme Alacaklarının Tahsil Usulü Hakkında Kanun İle Bazı Kanunlarda Değişiklik Yapılmasına Dair Kanun”un 27.maddesiyle 4447 Sayılı Kanunun 53.maddesinde yapılan değişiklik.

25 Ayrıca bu giderlere ek olarak 6645 sayılı Kanunun 24.maddesiyle 21 Eylül 2006 tarihli ve 5544 sayılı Meslekî Yeterlilik Kurumu Kanunu kapsamında yetkilendirilmiş sınav ve belgelendirme kuruluşlarının gerçekleştireceği sınavlarda başarılı olan kişilerin 31.12.2021 tarihine kadar belge masrafları ve sınav ücretleri ile 28 Ocak 2010 tarihli 5951 Sayılı "Amme Alacaklarının Tahsil Usulü Hakkında Kanun İle Bazı Kanunlarda Değişiklik Yapılmasına Dair Kanun”un 5.maddesiyle kısa çalışma başvurularında talebin uygunluğunun tespiti için Bakanlık tarafından 6245 sayılı Harcırah Kanunu kapsamında yapılan ve usul ve esasları Bakanlık ile Kurum tarafından müştereken belirlenen giderler Fondan karşılanmaktadır. 
öncelikli olmak üzere ekonomik kalkınma ve sosyal gelişmeye yönelik altyapı yatırımlarında kullanılmasına yönelik 2008-2013 yılları arasında Fondan yaklaşık 12 milyar lira Hazineye aktarılmıştır. Yine 2014 yılında Manisa'nın Soma ilçesinde 301 maden işçisinin hayatını kaybettiği Eynez Maden Ocă̆ 1 işletmesinde çalışanlara ve hayatını kaybedenlerin hak sahiplerine yapılan ödemeler ile Atabacası ve Iş̧ılar maden ocağı işletmelerindeki sigortalılara işveren tarafından ödenmeyen ücretler ve 2015 yılında Karaman ili Ermenek ilçesinde yaşanan maden kazasında hayatını kaybeden 18 işçinin hak sahiplerine yapılan ödemeler kapsamında yaklaşık 80 milyon lira Fondan karşılanmıştır. Bunlara ek olarak işverenlere sağlanan prim teşvikleri, işbaşı eğitim ve aktif işgücü programlarının masrafları ve pandemi nedeniyle ücretsiz izne çıkartılanlara ödenen nakdi ücret desteği ödemeleri Fonun giderek küçülmesine neden olmaktadır.

Tablo 2

İssizlik Sigortası Fonu Gelir ve Gider Tablosu (2016-2020)

\begin{tabular}{|l|c|c|c|c|c|}
\hline (Bin TL) & $\mathbf{2 0 1 6}$ & $\mathbf{2 0 1 7}$ & $\mathbf{2 0 1 8}$ & $\mathbf{2 0 1 9}$ & $\mathbf{2 0 2 0}$ \\
\hline Toplam Gelir & $\mathbf{2 2 . 2 7 3 . 4 8 0}$ & $\mathbf{2 6 . 8 6 2 . 3 6 9}$ & $\mathbf{3 4 . 6 2 8 . 5 2 9}$ & $\mathbf{4 0 . 3 6 5 . 3 6 8}$ & $\mathbf{3 8 . 2 7 0 . 4 4 3}$ \\
\hline İşçi ve İşveren Primi & 9.930 .192 & 11.66 .289 & 13.877 .888 & 16.547 .023 & 16.225 .243 \\
\hline Devlet Katkısı & 3.310 .064 & 3.895 .068 & 4.625 .963 & 5.515 .674 & 5.408 .411 \\
\hline Faiz Gelirleri & 8.025 .350 & 10.046 .217 & 15.108 .359 & 16.832 .038 & 15.749 .723 \\
\hline Diğer Gelirler & 1.007 .875 & 1.254 .795 & 1.016 .320 & 1.470 .633 & 887.066 \\
\hline Toplam Gider & $\mathbf{1 2 . 1 4 5 . 1 5 8}$ & $\mathbf{1 3 . 3 4 4 . 2 5 9}$ & $\mathbf{2 3 . 7 0 5 . 1 4 5}$ & $\mathbf{3 6 . 4 6 7 . 4 8 1}$ & $\mathbf{6 6 . 5 9 9 . 1 8 5}$ \\
\hline İşsizlik Ödeneği & 4.531 .026 & 4.895 .131 & 5.865 .518 & 10.006 .403 & 8.384 .775 \\
\hline Kısa Çalışma Ödeneği & 1.455 & 1.007 & 843 & 192.432 & 27.395 .624 \\
\hline $\begin{array}{l}\text { Yarım Çalışma } \\
\text { Ödeneği }\end{array}$ & 3.440 & 22.425 & 24.811 & 30.724 & 27.448 \\
\hline $\begin{array}{l}\text { Ücret Garanti Fonu } \\
\text { Ödemesi }\end{array}$ & 15.705 & 25.848 & 81.027 & 156.924 & 48.665 \\
\hline $\begin{array}{l}\text { Aktif İşgücü } \\
\text { Programları }\end{array}$ & 4.912 .229 & 3.771 .274 & 4.904 .236 & 6.579 .273 & 2.955 .297 \\
\hline $\begin{array}{l}\text { İşbaşı Eğitim } \\
\text { Programları }\end{array}$ & 1.556 .518 & 1.900 .276 & 1.851 .971 & 3.039 .028 & 2.690 .180 \\
\hline Nakdi Ücret Desteği & - & - & - & - & 6.536 .049 \\
\hline $\begin{array}{l}\text { Teşvik ve Destek } \\
\text { Ödemeleri }\end{array}$ & 910.364 & 2.504 .122 & 10.709 .430 & 16.058 .120 & 18.088 .597 \\
\hline Diğer Giderler & 214.422 & 224.176 & 267.308 & 404.546 & 472.548 \\
\hline Toplam Fon Varlığı & $\mathbf{1 0 3 . 2 0 2 . 4 1 2}$ & $\mathbf{1 1 6 . 7 2 0 . 5 2 2}$ & $\mathbf{1 2 7 . 6 4 3 . 9 0 6}$ & $\mathbf{1 3 1 . 5 4 1 . 7 9 3}$ & $\mathbf{1 0 3 . 2 1 3 . 0 5 0}$ \\
\hline Kayn: & - & &
\end{tabular}

Kaynak: https://www.iskur.gov.tr/kurumsal-bilgi/yayinlar/

Tablo 2'de 2016 ve 2020 yılları arasında İşsizlik Sigortası Fonunun gelir ve giderleri yer almaktadır. Fonun toplam varlığı 2020 yılına kadar artış göstermiş ancak gider kalemlerinin giderek artması ve pandemi sürecinde nakdi ücret desteği, kısa çalışma ödeneğini alan kişi sayısının artması, işverenlere yönelik 
teşvikler ve desteklerin artması gibi ek giderlerin de oluşması nedeniyle 2020 yılında azalmaya başlamıştır. 2020 yılında kuruluşundan bu yana toplam varlığ1 ilk kez azalan Fonun yine ilk kez toplam giderleri toplam gelirlerini aşmıştır. 2020 yılındaki bu olumsuz göstergelerde şüphesiz pandemi sürecinin etkisi çok büyüktür ancak pandemi öncesinde de Fonun gider kalemlerinin farklılaşması ve giderek artması en az pandemi sürecinin etkisi kadar büyüktür. Fonun toplam varlığ 2019 yılında yaklaşık 132 milyar lira iken 2020 yılında yaklaşık 103 milyar liraya ve 2021 yılı Nisan ayında ise yaklaşık 91 milyar liraya kadar gerilemiştir (İŞKUR, https://media.iskur.gov.tr/45001/03_ mart2021-bulten.pdf).

\section{Sonuç ve Değerlendirme}

İşsizliğin olumsuz sonuçlarını gidermeye yönelik oluşturulan pasif işgücü piyasası politikaları geçmişten günümüze işsizlikle mücadele kapsamında ön plan çıkan ve işsiz kalan bireylere gelir güvencesi sağlayan önemli politikalardır. Bu politikalar içerisinde iki temel uygulama olan kıdem tazminatı ve işsizlik sigortas1, Türkiye' de de uygulama alanı bulan politikalar arasında yer almaktadır. Türkiye'de kıdem tazminatı uygulaması 1936 yılında 3008 Sayılı İş Kanunu ile uygulanmaya başlanmış ve yapılan düzenlemelerle değişimlere uğrayarak günümüze kadar gelmiştir. İşsizlik sigortası uygulaması ise Türkiye'de kıdem tazminatına kıyasla çok daha geç uygulanmaya başlanan ve mazisi yeni olan bir pasif işgücü piyasası politikasıdır.

İşsizlik sigortası Türkiye'de 1999 yılında kabul edilen 4447 Sayılı Kanun ile birlikte uygulamaya konulmuş ve bu yıla kadar işsizlik sigortası olmayan tek OECD ülkesi Türkiye olmuştur. İşsizlik sigortasının bu kadar geç uygulamaya geçirilmesinin temel nedeni kıdem tazminatı uygulaması olmuştur. İşsizlik sigortası çalışmaları kıdem tazminatının varlığı nedeniyle sürekli ertelenmiş, işverenlere kıdem tazminatının yanında ağır bir yük oluşturacağı düşüncesiyle işveren kesiminden eleştiriler almıştır. Türkiye'de uygulanmakta olan bu iki önemli pasif işgücü piyasası politikası geçmişten günümüze sürekli fon tartışmaları ile gündeme gelmektedir. Kıdem tazminatı uygulamasında fon oluşturulması yönünde çalışmalar ve tartışmalar sürerken işsizlik sigortası uygulamasında ise mevcut fonun etkin bir şekilde kullanılamadığı yönünde eleştiriler yapılmaktadır. 
1950'li yıllarda başlayan kıdem tazminatı fonu oluşturma çalışmaları 1970'li yıllardan itibaren ciddi bir şekilde sürdürülmüş, 1999 yılında 4447 sayılı İşsizlik Sigortası Kanunu'nun yürürlüğe girmesi ve 4857 Sayılı İş Kanunu'nun iş güvencesini sağlamaya yönelik hükümlere yer vermesi nedeniyle de artarak günümüze kadar devam etmiştir. Mevcut kıdem tazminatı uygulamasında ortaya çıkan sorunlar da fon çalışmalarının üzerinde ciddiyetle durulması gerektiğini göstermektedir. Özellikle mevcut uygulamada, işverenlerin işçileri belirli süreli sözleşmelerle çalıştırması ve bir yıl dolmadan işe giriş çıkış yaptırması, iş sözleşmelerinin tazminata hak kazanamayacak biçimde sona erdirilmesi, işçiyi istifaya zorlama ya da kayıtdışı çalıştırma gibi nedenlerle işsiz kalanların büyük bir çoğunluğunun tazminatını alamamasına neden olmaktadır. Ayrıca işverenler de ekonomik kriz dönemlerinde işçi çıkarmak zorunda kaldıkları zamanlarda yüklü miktarlarda tazminat ödemeleriyle karşı karşıya kalmakta ve işgücü maliyetleri artmaktadır.

Yapılan fon çalışmalarında özellikle çalışılmış mevcut hakların ve fona aktarılacak prim oranının ne olacağı, fondan yararlanmak için belirli bir süre çalışmış olma şartının getirilmesi ve bazı özel durumlarda fonda biriken paranın bir kısmının alınabileceği, istifa eden işçilerin de tazminata hak kazanabilmesi gibi konularda ciddi tartışmalar söz konusu olmaktadır. Fon çalışmalarında kıdem tazminatı özellikle bireysel emeklilik, tamamlayıcı emeklilik sistemi gibi emeklilik sistemleri içerisine entegre edilmeye çalışılmaktadır. Bundaki en büyük etken de tasarrufların ve emeklilik gelirlerinin arttırılmasıdır. Ancak kıdem tazminatı işten çıkartılan çalışanların kıdemlerinin karşılığ 1 olarak hak ettikleri bir ücret alacağıdır. Dolayısıyla kıdem tazminatı, işçilerin istifa etmiş ${ }^{26}$ olsa bile işten ayrıldıklarında belirli bir süre prim ödeme şartı olmaksızın işsizliğin olumsuz sonuçlarının giderilmesi amacıyla hemen ödenmesi gereken önemli bir haktır. Yalnız tasarrufların ve emeklilik gelirlerinin arttırılması kapsamında özellikle işten çıkartılan çalışanlar hem işsizlik ödeneğine hem de kıdem tazminatına hak kazanıyorsa bu durumda fonda biriken işçinin alacağının emeklilik sonrasına bırakılması daha yerinde bir uygulama olacaktır.

26 İstifa eden çalışana kıdem tazminatının ödenmemesi Anayasa'nın 48.maddesi olan "herkes, dilediği alanda çalışma ve sözleşme hürriyetlerine sahiptir" hükmüyle çelişmektedir. Mesela, on yıldır çalıştığı işyerinden daha iyi koşullarda bir iş bulduğu için ayrılmak isteyen işçinin on yıllık kıdemini işverene terk etmesi, çalışma özgürlüğü ile bağdaşmamaktadır. Ayrıca kıdem tazminatı yanacak diye işinden ayrılamayıp daha iyi koşullarda çalışma firsatını kaçıran işçilerin emek hareketliliği de sınırlandırılmakta ve dolayısıyla çalışma hakkı engellenmektedir. 
Nitekim kıdem tazminatı, mevcut haliyle çalışanların çok küçük bir kesiminin yararlandığı bir uygulamadır. Dolayısıyla işveren tarafından ödenmeyen kıdem tazminatlarını garanti altına alacak bir sistemin oluşturulması ve bu kapsamda daha fazla çalışanın yararlandırılması gerekmektedir. Bu doğrultuda istifa eden olsun işten çıkartılan olsun iş sözleşmesi sona eren tüm çalışanların kıdem tazminatına hak kazanacağı bir kıdem tazminatı fonunun kurulması önemli bir ihtiyaçtır.

Türkiye'de 1999 yılından beri yürürlükte olan işsizlik sigortası uygulaması kapsamında kendi iradesi dışında işsiz kalan bireylere belirli sürede ve miktarda gelir güvencesi sağlanmaktadır. Yapılan işsizlik ödemeleri işçi ve işverenlerin ödemiş oldukları ve devletin de katkı yaptığı primlerle oluşturulan işsizlik sigortası fonundan karşılanmaktadır. İlk zamanlarda fonun sadece işini kaybedenlere yönelik olması ve dolayısıyla da gider kalemlerinin fazla olmaması fondaki miktarın giderek artmasını sağlamıştır. Ancak fonun bu kadar büyümesine rağmen işsizlik ödeneğinden yararlananların sayısına bakıldığında işsizlik sigortasının etkin olarak kullanılamadığını göstermektedir. Kuruluşundan bu yana işsizlik ödeneği almak için başvuranların neredeyse yarısı işsizlik ödeneğine hak kazanamamıştır. Bu durum ödeneğe hak kazanma şartlarının ağır olmasından kaynaklanmaktadır. Dolayısıyla bu şartların hafifletilmesi, ödenek miktarının ve süresinin arttırılması işsizlik sigortası kapsamında daha fazla işsizin yararlandırılmasını sağlayacaktır.

Fondaki miktarın giderek büyümesi fonun gider kalemlerinin artmasına yönelik düzenlemeleri de beraberinde getirmiş ve dolayısıyla da fonun giderlerinin sürekli olarak artmasına neden olmuştur. İşsizlik sigortasının sadece işini kaybedenlere değil tüm işsizlere kaynak aktarılmasına imkân vermesi, işsizlik sigortasından istihdamın arttırılması kapsamında işverenlere yönelik teşvik ve desteklerin verilmesi, çeşitli gerekçelerle bütçeye kaynak aktarılması ve pandemi sürecinde kısa çalışma ödeneği ve nakdi ücret desteği kapsamında yapılan ödemeler 2020 yılına gelindiğinde fondaki miktarın ilk kez azalmaya başlamasına neden olmuştur. Yapılan düzenlemelerle birlikte artan gider kalemleri neticesinde fondaki miktarın azalması kısa vadede fonun sürdürülemez bir duruma geleceğine işaret etmektedir. Dolayısıyla fonun sürdürebilirliğini ve etkinliğini sağlamak için gider kalemlerinin yeniden düzenlenmesi ve fondaki miktarın iyi değerlendirilmesi önem arz etmektedir. 
Tüm bunların 1şı̆̆ında oluşturulacak kıdem tazminatı fonunun, sosyal diyalog kapsamında işçi, işveren ve devlet arasındaki görüş ayrılıklarının giderilerek mutabakata varılmasıyla birlikte oluşturulması tartışmaların son bulmasını sağlayacaktır. Özellikle fon çalışmaları kapsamında işsizlik sigortası fonunun en iyi şekilde analiz edilerek ve fona yapılan eleştiriler dikkate alınarak kıdem tazminatı fonunun oluşturulması etkinliğini arttıracaktır. Ayrıca kayıtdışı istihdamın oluşmaması için fona aktarılacak olan prim oranının düşük tutulması durumunda meydana gelebilecek olası fon açıklarının işsizlik sigortası fonundan karşılanmaması gerektiği de fonun giderlerinin artması kapsamında önem arz etmektedir.

Nitekim yapılacak aktüeryal hesaplamalarla mevcut kıdem tazminatı uygulamasına kıyasla hem işverenlerin işgücü maliyetlerini azaltacak hem de işçilerin tazminatlarını azaltmayacak aynı zamanda da fonun sürdürülebilirliğini sağlayacak bir prim oranının belirlenmesi çok önemli bir noktayı oluşturmaktadır. Dolayısıyla oluşturulacak fondaki miktarın yatırım araçlarıyla iyi bir şekilde değerlendirilmesi gerekmektedir. Bu durum fonun doğrudan etkilerinin yanı sıra ulusal tasarrufu artırmaya yönelik bir etki yapabileceği ve ekonomiyi olumlu olarak etkileyebileceği gibi dolaylı etkilerinin de ortaya çıkabileceğini göstermektedir.

Hakem Değerlendirmesi: Dış bağımsız.

Çıkar Çatışması: Yazar çıkar çatışması bildirmemiştir.

Finansal Destek: Yazar bu çalışma için finansal destek almadığını beyan etmiştir.

Yazar Katkısı: xxxxxxxxxxxxxxxxxxxxxxxxxxxxxxxxxxxxxxxx 


\section{Kaynakça/References}

Aktay, N., vd. (2006). İş Hukuku. Ankara: Seçkin Yayıncılık

Anadolu Ajansı (2017). “Çalışanların Yüzde 70’i Kıdem Tazminatı Fonundan Yararlanamiyor", https://www.aa.com.tr/tr/turkiye/calisanlarin-yuzde-70i-kidemtazminati-fonundan-yararlanamiyor/796392, 03.01.2021

Anadolu Ajansı (2020). “A'dan Z'ye Tamamlayıcı Emeklilik Sistemi”, https://www. aa.com.tr/tr/ekonomi/adan-zye-tamamlayici-emeklilik-sistemi/1878484, 06.03.2021

Arıcı, K. (2010). “İnsan Onuruna Yakışır İş Perspektifinde İşsizlik Sigortası Fonunun Yönetimi ve Sürdürülebilirliği”, (Haz.) Tan, N. ve Karslığlu, G., İşsizlik Sigortası Fonu'ndan Elinizi Çekin, Ankara, TÜRK-İŞ, 171-188

Aygören, H., vd. (2012). K1dem Tazminatı Fonu’nun Aktüeryal Prim Oranı Hesaplamaları ve Muhasebesi. Muhasebe ve Finansman Dergisi, 54, 123-140

Balcı, Y. ve Ersöz, H. Y. (1997). Kıdem Tazminatı Fonu-Bir Model Önerisi, MÜSİAD Araştırma Raporları-22, İstanbul, UTESAV

Başterzi, S. (1996). İşsizlik Sigortası, Ankara, Ankara Üniversitesi Hukuk Fakültesi Yayınları No: 509

Baydere, F. (1966). İş Mevzuatına Tesirleri Bakımından Çalışma Meclisleri. Sosyal Siyaset Konferanslarl Dergisi, 17, 212-222

Biçerli, M. K. (2011). Çalışma Ekonomisi, (6.bs). İstanbul: Beta Yayınları

Çelik, A. (2015). Dünyada ve Türkiye'de Kıdem Tazminatı Uygulamaları. İktisat Dergisi, 530, 27-39

Çelik, N. (2007). İş Hukuku Dersleri, (20. bs.). İstanbul: Beta Yayınları

ÇSGB (2013). 10. Çalışma Meclisi, Ankara, Çalışma ve Sosyal Güvenlik Bakanlığı

ÇSGB (1998). ILO Anayasası ve Türkiye Cumhuriyeti Tarafından Onaylanan ILO Sözleşmeleri, Ankara, Çalışma ve Sosyal Güvenlik Bakanlığı, Araştırma Planlama ve Koordinasyon Kurulu Başkanlığı, Yayın No: 86

ÇSGBa (2015). Ulusal İstihdam Stratejisi 2014-2023-Eylem Planları 2014-2016, Ankara, ÇSGB Çalışma Genel Müdürlüğü

ÇSGB (2017). Ulusal İstihdam Stratejisi 2014-2023-Eylem Planları 2017-2019, Ankara, ÇSGB Çalışma Genel Müdürlüğü

ÇSGBb (2015). 11. Çalışma Meclisi, Ankara, Çalışma ve Sosyal Güvenlik Bakanlığı

ÇSGB (t.y.). Kıdem Tazminatı Fonu Kanun Tasarısı Taslağı, Ankara, Çalışma ve Sosyal Güvenlik Bakanlığı, Genel Yayın No: 118,

Doğan, B. B. ve Yıldırım, E. A. (2016). Kıdem Tazminatı ve Ülke Örnekleri. Dicle Üniversitesi İktisadi ve İdari Bilimler Fakültesi Dergisi, 6(10), 16-31

Gençler, A. (2002). Türkiye'de İşsizlik Sigortası Uygulaması. Çimento İşveren Dergisi, $16(3), 3-22$

Güner, Z. B. vd. (2016). Türkiye İçin Kıdem Tazminatı Fonu Oluşturulmasına Yönelik Model Önerileri. Sosyal Güvence Dergisi, 5(10), 25-52 
Holmlund, B. (1998). Unemployment Insurance in Theory and Practice. Scandinavian Journal of Economics, 100(1), 113-141

Holzmann, R., vd. (2011). Severance Pay Programs around the World: History, Rationale, Status, and Reforms, World Bank and IZA, Discussion Paper No. 5731

İ̧SUR, https://www.iskur.gov.tr/kurumsal-bilgi/yayinlar/, 15.02.2021

Kapar, R. (2005). Sosyal Korumanın İşgücü Piyasasına Etkisi, İstanbul, Birleşik Metal-İş̧ Yayınları, Yayın No: 17/2005

Kaya, P. A. (2005). Türk İş Hukukunda Kıdem Tazminatı Tartışmaları. İş, Güç-Endüstri Illişkileri ve İnsan Kaynakları Dergisi, 7(1), 179-193

Kıdem Tazminatının İşçinin Bireysel Hesabına Yatııılması Hakkında Kanun Taslağı, https://www.petrol-is.org.tr/sites/default/files/kt.yenitaslak.7.12.doc, 15.02.2021

Koç, Y. (2020). "Kıdem Tazminatı Fonu Kanun Taslakları Tarihi”, Aydınlık Gazetesi, 29 Haziran 2020, https://www.yildirimkoc.com.tr/usrfile/1593528969b.pdf, 15.02.2021

Korkmaz, A. ve Mahiroğulları, A. (2007). İşsizlikle Mücadelede Emek Piyasası Politikaları, Türkiye ve AB Ülkeleri, (2.bs). Bursa: Ekin Yayınevi

Kutal, M. (2009). Türk İş Hukukunda Kıdem Tazminatı Sorunu ve Çözüm Önerileri. Sicil, 16, 5-14

Kutal, M. (2002). “Türk İşsizlik Sigortasında Sigortalılara Sağlanan Yardımlar ve Bunları Yapmakla Görevli Resmi Kuruluşlar”, İşsizliğin İş Hukuku ve Sosyal Güvenlik Açısından Sorunları Semineri, Ankara, Kamu-İ̧̧ Yayınları, 171-182

Limon, R. (2015). Türkiye'de Kıdem Tazminatının Tarihi Gelişimi ve Kıdem Tazminatı Fonu. İşv ve Hayat Dergisi, Türkiye Glda ve Şeker Sanayi Iş̧̧̧ileri Sendikası, 1, 147-170

Limoncuoğlu, S. A. (2010). "Karşılaştırmalı Hukukta Kıdem Tazminatı Uygulamaları", Asomedya, Ankara Sanayi Odası Yayın Organı, Ocak/Şubat, 45-62

Milliyet Gazetesi (2020). "Kıdem Tazminatı Vermemek İçin Girdi-Çıktı Oyunu Bitecek", https://www.milliyet.com.tr/galeri/kidem-tazminati-vermemek-icin-girdi-ciktioyunu-bitecek-6246724,03.01.2021

Narmanlıoğlu, Ü. (1998). İş Hukuku-Ferdi İş İlişkileri 1, İzmir, Dokuz Eylül Üniversitesi Hukuk Fakültesi Yayını

Nurdoğan, A. K., vd. (2016). Türkiye'de ve Dünya'da Kıdem Tazminatı Fonu. Süleyman Demirel Üniversitesi İktisadi ve İdari Bilimler Fakültesi Dergisi, 21(4), 1153-1171

Okay, S.N. (1975). Kıdem Tazminatı Müessesesi ve Türkiye'de ki Uygulaması. Sosyal Siyaset Konferanslart Dergisi, 26, 104-124

Orta Vadeli Program (2013). T. C. Resmi Gazete, Say1: 28789 (Mükerrer), 08.10.2013

Özveri, M. (2005). “Kıdem Tazminatı ve Kıdem Tazminatı Fonu Yasa Tasarısı”, Mesleki Sağlık ve Güvenlik Dergisi, Türk Tabipler Birliği, Nisan-Mayıs-Haziran, 16-20 
Sabah Gazetesi (2016). “Çalışma Bakanı Soylu'dan Kıdem Tazminatı Açıklaması”, https://www.sabah.com.tr/ekonomi/2016/06/14/calisma-bakani-soyludan-kidemtazminati-aciklamasi, 03.01.2021

Siebert, H. (1997). Labor Market Rigidities and Unemployment in Europe, The Kiel Institute of World Economics Kiel Working Papers, No. 787

Süzek, S. (2008). İş Hukuku (4. bs.). İstanbul: Beta Yayınları

Sümer, H. H. (2010). İş Hukuku Uygulamaları (4. bs.). Konya: Mimoza Yayınları

Şakar, M. (2016). İş Hukuku Uygulaması (11. bs.). İstanbul: Beta Yayınları

Şakar, M. (2016). Kıdem Tazminatı Fonu Kurulabilir mi? Mali Çözüm, 137, 13-24

Şen, M. (2019). “Türkiye'de İstihdam ve İşsizlik: İşsizlikle Mücadelede İşgücü Piyasası Politikaları”, (Ed.) Şen, M. ve Murat, G., Küreselleşme Sürecinde Türkiye'de Sosyal Politika, Bursa, Ekin Yayınevi, 133-207

Taşçı, F. ve Yılmaz, Y. (2009). İşsizlik Sigortasının Türkiye'deki Durumu: Eleştiriler ve Çözüm Önerileri. Sosyal Siyaset Konferansları Dergisi, 56, 601-637

T.C. Cumhurbaşkanlığı (2013). Onuncu Kalkınma Planı (2014-2018), Ankara, Strateji ve Bütçe Başkanlığı

T.C. Cumhurbaşkanlığı (2019). Onbirinci Kalkınma Planı (2019-2023), Ankara, Strateji ve Bütçe Başkanlığ

TC. Aile, Çalışma ve Sosyal Hizmetler Bakanlığı, https://ailevecalisma.gov.tr/tr-tr/ istatistikler/calisma-hayati-istatistikleri/kidem-tazminati/kidem-tazminati-tavanmiktari/, 25.03.2021

Törüner, M. (1992). İşsizlik Sigortası, İstanbul, Friedrich Ebert Vakfı

Tuncay, A.C. ve Ekmekçi, Ö. (2011). Sosyal Güvenlik Hukuku Dersleri (14.bs.). İstanbul: Beta Yayınları

Tunçomağ, K. ve Centel, T. (2016). İş Hukukunun Esasları (8. bs.). İstanbul: Beta Yayınları

Uluğ, G. (2007). "Kıdem Tazminatı: Türkiye ve Kanada Örneği”, Yayımlanmamış Doktora Tezi, İstanbul Üniversitesi Sosyal Bilimler Enstitüsü, İstanbul.

Ünsal, E. (2008). Kıdem Tazminatı Fonu Kanun Tasarısı Taslağı Konusunda Bazı Düşünceler. TÜHIS Işs Hukuku ve İktisat Dergisi, 21(2-3), 31-39.

Vandaele, K. (2006). A Report From The Homeland Of The Ghent System: The Relationship Between Unemployment and Trade Union Membership in Belgium. Transfer: European Review of Labour and Research, 12(4), 647-657

Varçın, R. (2004). İstihdam ve İşgücü Piyasası Politikaları. Ankara: Siyasal Kitabevi

Yazgan, T. (1969). Türkiye’de İşsizlik Sigortasının Kurulması İle İlgili Meseleler. Sosyal Siyaset Konferanslarl Dergisi, 20, 151-167 
Yıldız, K. ve Akçay, H. (2016). Türkiye'de Kıdem Tazminatının Ödenme Oranı ve Ödenmeme Sebepleri. Balıkesir Üniversitesi Sosyal Bilimler Enstitüsü Dergisi, 10. Yıl Özel Sayısl, 19(36-1), 747-767

Zaim, S. (1997). Çalışma Ekonomisi (10.bs.). İstanbul: Filiz Kitabevi

World Bank Group (2018). "Doing Business 2018-Reforming to Create Jobs", A World Bank Group Flagship Report, Washington

2020 Yılı Cumhurbaşkanlığı Yıllık Programı (2019). T. C. Resmi Gazete, Sayı: 30938 (Mükerrer), 04.11.2019 